\title{
Bankruptcy Shocks and Legal Labor Markets: Evidence from the Court Competition Era
}

\author{
Chad Brown* Jeronimo Carballo ${ }^{\dagger} \quad$ Alessandro Peri ${ }^{\ddagger}$
}

February 2, 2022

\begin{abstract}
We study how Chapter 11 bankruptcies affect local legal labor markets. We document that bankruptcy shocks increase county legal employment and corroborate this finding by exploiting a stipulation of the law known as Forum Shopping during the Court Competition Era (1991-1996). We quantify losses to local communities from firms forum shopping away from their local area as follows. First, we calculate the unrealized potential employment gains implied by our reduced-form results. Second, we structurally estimate a model of legal labor markets and quantify welfare losses. We uncover meaningful costs to local communities from lax bankruptcy venue laws.
\end{abstract}

Keywords: bankruptcy, legal sector, forum-shopping, labor market shocks, welfare analysis.

JEL codes: K00, J00, G33, J44, J20.

*Department of Economics, University of Colorado Boulder, 80309, USA. chad.brown@colorado.edu

${ }^{\dagger}$ Department of Economics, University of Colorado Boulder, 80309, USA. jeronimo.carballo@colorado.edu

${ }^{\ddagger}$ Department of Economics, University of Colorado Boulder, 80309, USA. alessandro.peri@colorado.edu 


\section{Introduction}

Legal expenses are often treated as dead-weight loss from bankruptcy proceedings (e.g. Franks, Nyborg, and Torous 1996; Armour, Hsu, and Walters 2012; M. M. Buehlmaier 2014; Mahoney 2015). However, they are meaningful transfers to crucial stakeholders of bankruptcy events: professionals employed in the legal service sector. In this paper, we illustrate how failing to account for these transfers overlooks a potential source of economic stimulus, which acts in opposition to the overall contractionary effect that large bankruptcies have on local employment (Bernstein et al. 2019). We provide first evidence that local legal labor markets indeed benefit from the increased demand for legal services created by bankruptcies. We then illustrate how lax bankruptcy venue laws and competition among courts may nullify this effect, by exporting away these potential gains from the affected communities. Finally, we develop a structural model of the legal sector and quantify economically meaningful welfare losses in the bankrupt firm's surrounding area from firms who file in courts far from their local communities.

Little is known about the effect of corporate bankruptcies on local legal employment. For example, it could be negligible if distressed firms hired legal services from a different locale, or if legal firms responded to the bankruptcy shock by partially increasing their employees' working hours or by reassigning them from other cases. Our first contribution is to document a positive and economically significant effect.

Using a novel database of Chapter 11 bankruptcies of publicly traded firms, we estimate that during the early 90's bankruptcy reorganizations are associated with a $1 \%$ increase in annual legal employment for the affected county for each ongoing bankruptcy. Aggregated across the U.S. this means that each year roughly 10,000 jobs - with wages adding up to nearly $\$ 1$ billion in 2021 dollars - are being distributed to communities dealing with the contractionary effects associated with a major employer filing for bankruptcy. Crucially, we

document that these employment gains are lost when firms file for bankruptcy in courts that are far away from their headquarters, a phenomenon referred to as forum shopping. We find evidence that forum shopping exported away more 
than $24 \%$ of the potential employment gains from local communities with distressed firms each year during the Court Competition Era (1991-1996). Building on the work of Notowidigdo (2020), we structurally estimate a labor model of the legal sector and document $\mathrm{a} \approx 1 \%$ consumption equivalent variation loss in affected communities as a result of forum shopping.

Identifying the causal impact of bankruptcy shocks on local legal sector labor markets is not straightforward. Unlike the applied economics literature that exploits an event study framework, our research design setting is not conducive to such methods due to transitory and repeated treatment (Callaway and Sant'Anna 2021; Sun and Abraham 2020). In order to address this problem, we need a shock that is: (i) economically meaningful; (ii) exogenous to the local demand for legal services; and (iii) addresses the complex nature of our treatment. We overcome this challenge by measuring demand shocks to local legal services using Chapter 11 reorganization bankruptcies of publicly traded firms.

First of all, Chapter 11 bankruptcies act as a considerable demand shock to local legal services. These bankruptcy cases are complex phenomena that arbitrate over the conflicting interests of several stakeholders: creditors, shareholders, workers, managers, and so forth. Consequently, firms will often pay fees in the order of hundreds of millions of dollars ${ }^{1}$ for legal teams that range from a handful of highly trained consultants and attorneys, to teams of legal clerks and paralegals. Although it is common for firms to formulate a reorganization plan using a handful of bankruptcy experts from major hubs (like New York, LoPucki 2005), much of the impact of these shocks will be concentrated in the area surrounding whatever bankruptcy court the case was filed in. Lawyers representing the interested parties must be certified to practice in that area (Okray 2016), familiar with local bankruptcy practices (Leary, Niemic, and Deckman 1999), as well as able to attend to other in-person obligations at the courthouse (e.g. bankruptcy filings, monitoring the docket, providing local counsel). Therefore, Chapter 11 bankruptcy shocks act as meaningful shocks to a local area.

Second, Chapter 11 bankruptcy filings of publicly traded firms provide a

\footnotetext{
${ }^{1}$ For instance, the professional fees in Kodak bankruptcy case rounded up to $\$ 240 \mathrm{M}$ in 2013. Source: Reuters. Professional fees averaged $\$ 82$ million in 2021 dollars in the UCLALopucki Bankruptcy Research Database over the period 1980-2014.
} 
plausible source of exogenous variation in the local demand for legal services. The large/multi-national nature of the demand faced by publicly-traded firms decouples the determinants of firms' bankruptcy choices from the well being of the local economy. To illustrate this point anecdotally, consider the Chapter 11 bankruptcy of Kodak, the well-known photography company from Rochester, New York. Economic fluctuations in Rochester played little to no role in Kodak's decision to file for bankruptcy reorganization in 2012 - which was instead motivated by the worldwide decline in the popularity of film photography. In Section 3.5.1, we document this exogeneity empirically.

Third, we leverage well-documented Chapter 11 forum shopping practices during the 90 s to handle the complex nature of our treatment. Counties experiencing treatment (Chapter 11 bankruptcy shocks) are often treated multiple times, can switch back and forth between treated and untreated from year to year, and do not share a clear pre-treatment and post-treatment period. We contribute to previous bankruptcy literature (e.g. Bernstein et al. 2019; Chava, Malakar, and Singh 2021) by proposing a novel identification strategy to handle the transitory and repeated nature of the treatment. In place of an event study framework, we exploit forum shopping to create exogenous variations in the location of demand for legal service and verify our identification. When a firm forum shops, the legal sector demand shock is effectively exported away from their local economy. This transfer in potential legal service demand is particularly pronounced because firms typically forum shop considerable distances away from their local area. For large publicly traded corporations who forum shop the average distance from their headquarters to the court they filed in is 766.1 miles. This is a drastic increase from 18.9 miles for firms who did not forum shop. ${ }^{2}$

To use forum shopping as an 'institutional placebo', we follow an economic history approach and focus on a period where the determinants of firms' forum shopping decisions are clearly documented by the bankruptcy literature and arguably exogenous to local economic conditions: the 'Court Competition Era',

\footnotetext{
${ }^{2}$ Figures are calculated using the UCLA-Lopucki Bankruptcy Research Database.
} 
1991-1996 (Section 2). ${ }^{3}$ From 1991 through 1996 bankruptcy judges began competing for prestigious and lucrative Chapter 11 filings (Eisenberg and LoPucki 1999), which encouraged firm's to exploit stipulations of US bankruptcy law to file for bankruptcy far away from their headquarters, i.e. forum shop (e.g. LoPucki 2005; LoPucki 2006; LoPucki and Kalin 2000; Eisenberg and LoPucki 1999; Cole 2003). Over this short period of time, the share of forum shopped bankruptcy cases tripled (Figure 1), from 20\% in 1990 to a new long run average of $60 \%$, which persists until today (Ellias 2019). Importantly, the bankruptcy literature suggests that forum shopping in this period is driven by incentives to seek favourable judges and is largely decoupled from local conditions (e.g. Eisenberg and LoPucki 1999; LoPucki 2005; LoPucki 2006; Gennaioli and Rossi 2010). ${ }^{4}$ In Section 3.5.2, we complement this literature and provide supportive evidence for the exogeneity of forum shopping with respect to unobserved factors correlated with attributes of local legal labor markets.

For our analysis, we construct a novel database that expands the universe of large bankruptcies in the widely used UCLA-Lopucki Bankruptcy Research Database (Lopucki BRD) with bankruptcy information of publicly traded firms in Standard and Poor's Compustat Database (CS), supplemented with information using the Public Access to Court Electronic Records (PACER) service. ${ }^{5}$ After aggregating this information at the county level, we estimate a regression with county fixed effects, judicial district-year fixed effects, and county-year controls.

Our reduced-form analysis in Section 4.2 confirms that the observed changes in local legal employment following bankruptcy shocks are contingent on firms filing for bankruptcy in their local court. Thus, when firms file in a court that is far from their local area (i.e. forum shop) any impact on the legal sector is

\footnotetext{
${ }^{3}$ For example, Cunningham and Shah (2014) use a similar strategy to obtain identification. They use an institutional change where a Rhode Island judge unexpectedly decriminalized indoor prostitution to create exogenous variation in the availability and legality of sex services. As such they restrict their attention to the period from 2004 to 2009 when this institutional change was in effect. For other examples, see Rajan and Ramcharan (2015), Hausman (2016).

${ }^{4}$ See Gennaioli and Rossi (2010) for a study of the incentives structure of judges with career concerns to compete for prestigious Chapter 11 reorganizations.

${ }^{5}$ Web BRD (the "LoPucki") database can be found at http://lopucki.law.ucla.edu.
} 
essentially exported away. This result indicates that it is the bankruptcy filing causing the measured effect and not confounding factors correlated with the bankruptcy. ${ }^{6}$

Our reduced-form results are stable to a variety of robustness checks. Most notably, to ease concerns about the relevance of the comparison group we limit our sample to only counties that could plausibly be treated. We also run various specifications that show potential spillover effects to neighboring counties is negligible. Additionally we find our results to be robust to several other considerations such as: using alternative data sources or alternative measures of treatment, including additional county characteristic controls, and dropping years potentially impacted by recessions.

Besides providing a convenient 'institutional placebo' to verify our identification, forum shopping practices have potentially important welfare consequences on the affected communities. To explore these effects, in Section 6 we build on Notowidigdo (2020) and construct a parsimonious model of the legal labor market. $^{7}$ In the model economy, a representative firm produces legal services using two inputs of production that act as imperfect substitutes: skilled labor (attorneys) and less productive unskilled labor (paralegals, law clerks, etc.). In the spirit of Bai, Rios-Rull, and Storesletten (2012), bankruptcy demand shocks enter this model akin to "productivity" shocks to the production function of legal services, boosting the demand of legal workers and their welfare.

We calibrate the model parameters using a nonlinear simultaneous-equations generalized method of moments (GMM) procedure that exploits non-forum shopped bankruptcies as exogenous demand shocks for the local area. Using this novel identification approach, we provide first empirical estimates for the elasticity of labor supply of skilled and unskilled workers in the legal industry. This finding adds to the body of literature that estimates the Frisch elasticity of labor supply for the extensive margin (e.g. Bianchi, Gudmundsson, and Zoega

\footnotetext{
${ }^{6}$ For example, we would still observe an increase in legal employment after forum shopping if the increase in legal employment was due to confounding factors associated with the bankruptcy event, such as spikes in divorces or wrongful termination lawsuits.

${ }^{7}$ Our model is a specialization of the canonical labor model used for studying how shocks effect labor market outcomes across skill levels (Acemoglu 2002; Acemoglu and Autor 2011; Bowlus et al. 2017).
} 
2001; K. M. Brown 2013; Rogerson and Wallenius 2009). We provide insights into the labor markets of an industry that plays a key role in the functioning of modern economic societies (Bennett, Milbourn, and Wang 2018), but has been comparatively understudied with respect to similarly-sized sectors, like agriculture. $^{8}$

Our calibrated model allows us to to quantitatively estimate the local welfare implications of forum shopping. To do so we calculate the potential welfare gains associated with moving from the status-quo regime where firms forum shop to a counterfactual regime without forum shopping. We find that legal sector workers in affected communities would need roughly a $1 \%$ increase in there annual consumption to receive the same level of utility they would have had without forum shopping.

These results additionally contribute to the debate in the law literature over the efficiency of forum shopping and court competition for bankruptcy outcomes (e.g. Zywicki 2006; Thomas and Rasmussen 2001; Eisenberg and LoPucki 1999; LoPucki and Kalin 2000; LoPucki 2006; Lee 2011), by providing first evidence of unintended consequences on the local economy. Accordingly, our findings have direct economic relevance on the ongoing policy debate in the U.S. Congress about the Bankruptcy Venue Reform Act. On June 28, 2021 the U.S. Representatives Zoe Lofgren and Ken Buck introduced the bipartisan Bankruptcy Venue Reform Act to the U.S. House of Representatives. If passed, the Reform Act will put a halt to the practice of forum shopping, the ability of firms to file for a bankruptcy court located in a different place than the principal assets or place of business. The purpose of the bill is to protect the interests of affected stakeholders (local creditors, retirees and employees) by having the case processed by a judge familiar with the community ${ }^{9}$ and put to an end "the single most significant source of injustice in Chapter 11 bankruptcy cases". ${ }^{10}$ Our analysis suggests that a deeper look at the production network

\footnotetext{
${ }^{8}$ In 2019 the legal industry GDP measured 280 billion, while the US agricultural sector measured 175 billion. Source: U.S. Bureau of Economic Analysis 1997.

${ }^{9}$ See press release Lofgren, Buck Introduce Bipartisan Legislation to End Corporate Bankruptcy Forum Shopping, from Rep. Lofgren. Source: Press Release.

${ }^{10}$ City of Detroit's Bankruptcy Judge Steven Rhodes, National Conference of Bankruptcy Judges, 2018. Source: NCBJ Special Committee.
} 
of large corporate bankruptcy cases uncovers economically significant costs to local communities, so far unaccounted for by the policy debate.

\section{Forum Shopping and the Court Competition Era}

The U.S. federal courts system is organized in 90 judicial districts which handle bankruptcy cases. ${ }^{11}$ Pursuant to 28 U.S.C. $§ 1408$, distressed firms can file for Chapter 11 reorganization in any judicial district with jurisdiction over the location of their (1) "principal place of business"; (2) "principal assets"; (3) "domicile"; or in which (4) the debtor's affiliate, general partner, or partnership has a pending bankruptcy case. The practice of filing in a venue which is located in a district different from the principal place of business or principal assets is referred to as forum shopping. Consistent with the previous bankruptcy literature, we follow the procedure adopted by the Lopucki BRD and consider the firms' headquarters to be the locale of the principal place of business or principal assets.

The period from 1991 through 1996 witnessed an explosion in forum shopped filings across the U.S. In the brief time window of six years, the share of forum shopped cases nearly tripled, leveling off at roughly 60\% in 1997 from an average of $25 \%$ prior to 1991 (Figure 1). Many bankruptcy scholars attribute this boom in forum shopping to an intense competition between the Southern District of New York and the District of Delaware, driven by judges who wished to attract prestigious and lucrative large Chapter 11 filings $^{12}$ (e.g. LoPucki and Kalin 2000; LoPucki 2006; LoPucki 2005; Gennaioli and Rossi 2010).

While New York was the favored destination for forum shopping prior to the 1990's, this abruptly changed in the early 90's when Delaware emerged as a prominent forum shopping destination. Delaware's meteoric rise in popularity marked the beginning of the 'Court Competition Era'. Firms started exploiting

\footnotetext{
${ }^{11}$ In our analysis, we do not include the district court for Puerto Rico or the territorial courts for Guam, the Northern Mariana Islands, or the Virgin Islands.

${ }^{12}$ Cole (2003) finds that "[a]lmost all of the judges suggested that there is a level of prestige and satisfaction that attaches to hearing and deciding important cases....'Big Chapter 11 cases are interesting as well as prestigious." For a model of judicial discretion in corporate bankruptcy, see Gennaioli and Rossi 2010.
} 


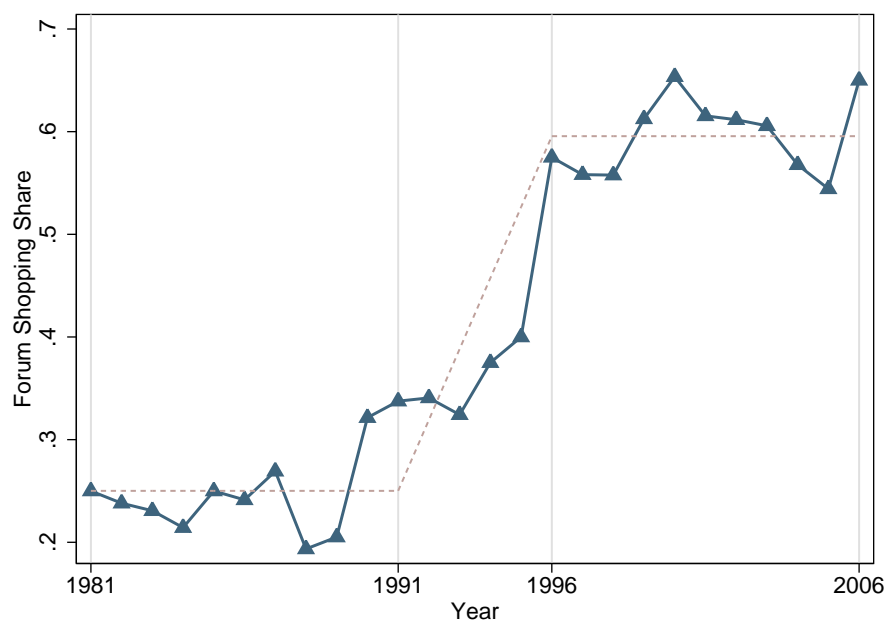

Figure 1: Share of Forum Shopped Bankruptcies - Share of the Chapter 11 Bankruptcies that were Forum Shopped annually from 1981 to 2006. Dashed lines show the average share of forum shopped Ch11 bankruptcies before and after the court competition era, and the change in the average over the court competition era. Due to limited data availability for the extended period, the figure only uses data from the Lopucki BRD for large firm bankruptcies.

the flexible venue criteria to "shop around"13 for a venue where they believed judges would be more likely to rule in their favor. Figure 2 illustrates the extent of New York and Delawares prominence during this time.

This trend of forum shopping and court competition continued through 1996. Then controversy over this trend caused the National Bankruptcy Review Commission to propose a reform that would have essentially eliminated debtors from filing in Delaware (Skeel 1998 p. 1-2). In 1997, to avoid this impending legislation, the Chief Judge of the Delaware District Court made an order to reduce the number of filings from forum shopping debtors as well as reduce the ability for judges to compete for prestigious bankruptcy cases (Skeel 1998; LoPucki and Kalin 2000). ${ }^{14,15}$ So, while Delaware remains a hotbed for forum shopping even

\footnotetext{
${ }^{13}$ LoPucki and Whitford (1991) lists several examples of companies "venue hook", where firms select a venue by quickly transferring headquarters to a small office near their preferred court shortly before filing. In addition after a 1989 ruling firms were also able to exploit flexible criteria for place of incorporation to forum shop.

${ }^{14}$ Skeel (1998) (p. 33-35), also offers other explanations but stresses the importance of the proposal for the Judge's order.

${ }^{15}$ See LoPucki and Kalin (2000) p. 234- Delaware Senator Joseph Biden controlled bankruptcy legislation in the Senate and is speculated to have not put the law to a vote
} 


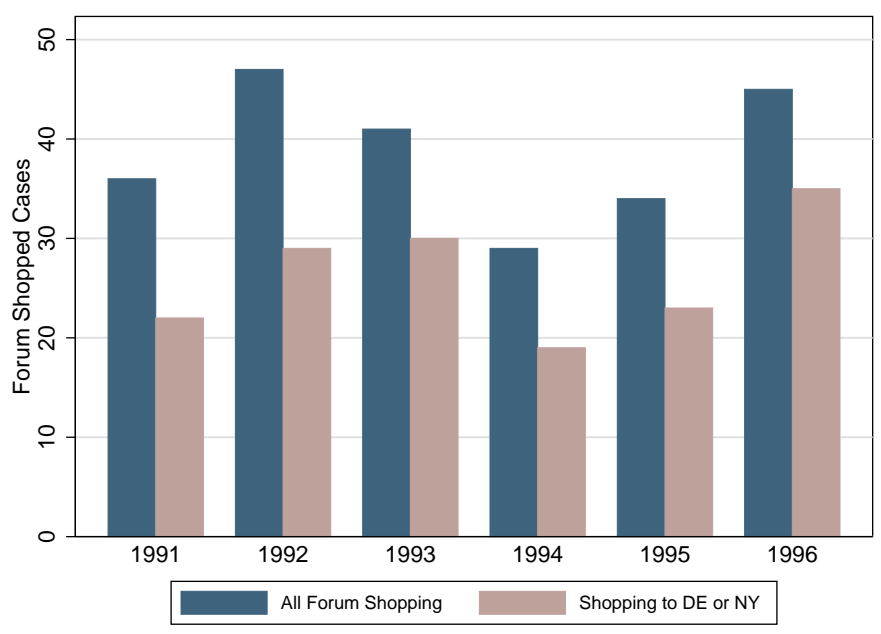

Figure 2: Forum Shopped Bankruptcies - Number of Forum Shopped Ch11 Bankruptcies filing in Delaware or New York Southern vs total number of Forum Shopped Ch11 Bankruptcies.

today, the reduction in court competition among judges has made the motives and outcomes of forum shopping less clear (Lee 2011).

\section{Empirical Analysis}

This section lays out the empirical strategy for estimating the impact of Chapter 11 bankruptcies on local legal markets. Section 3.1 describes the construction of our Chapter 11 bankruptcy database. Section 3.2 describes our main estimation sample and Section 3.3 shows descriptive statistics for bankruptcy treatment during the sample. Section 3.4 presents our empirical methodology. Finally, Section 3.5 tests that Chapter 11 bankruptcies in our sample are exogenous to local conditions, and that forum shopping decisions are unrelated to local legal market conditions. Henceforth, bankruptcy refers only to Chapter 11 cases.

\subsection{Data}

Our main database covers the period 1991-1996 and includes county level data for all U.S. states. This amounts to 18,373 county-year observations. The

to allow Delaware to deal with the problem on their own terms and allow forum shopping to continue in a reduced form. 
database includes annual-county data from the County Business Pattern (CPB) database. For each county, it also includes detailed data on bankruptcies and forum shopping for firms headquartered in the county. The bankruptcy information combines firm-level bankruptcy information from the UCLA-Lopucki Bankruptcy Research Database (Lopucki BRD) and Standard and Poor's Compustat Database (Compustat) with public court records. In the next subsection, we explain how we construct our main database. Additional details can be found in Appendix H.

\subsubsection{Bankruptcy Data}

Our bankruptcy database integrates the Lopucki BRD with bankruptcy information from Compustat and public court records over the period 1991-1996.

The Lopucki BRD contains information on 182 Chapter 11 bankruptcy cases of large publicly listed US companies during 1991-1996. Firms qualify as large public companies only if they file a 10-K form with the SEC that reports assets worth at least $\$ 100$ million in 1980 dollars (about $\$ 300$ million in 2021 dollars).

We complement this database with bankruptcy information of smaller publicly listed firms from Compustat. This database contains panel data on 13,277 publicly traded US firms over 1991-1996. We follow the procedure in Corbae and D'Erasmo (2021) to determine Chapter 11 bankruptcy events in our sample (see Appendix H). We then turn to publicly available SEC filings and Court records to identify the bankruptcy cases that have been forum shopped. ${ }^{16} \mathrm{We}$ proceed in two steps. First, we use these records to determine the location of the court of filing for each bankruptcy. Second, we establish that a bankruptcy case has been forum shopped if the bankruptcy was filed in a different judicial district than where the firm's headquarter is located. By doing so, we integrate the Lopucki BRD with additional 385 bankruptcy cases, of which $18 \%$ were forum shopped.

\footnotetext{
${ }^{16}$ Sources: SEC.gov — EDGAR - Search and Access, and PACER Case Locator, supplemented by bloomberglaw.com as needed.
} 


\subsubsection{Local Economic Attribute Data}

We use County Business Patterns (CBP) data from the US Census Bureau to measure the county-year level of employment (as imputed by Eckert et al. 2019) in the legal sector for our dependent variable, and to construct different controls (such as employment in non-legal sectors) for our empirical analysis. ${ }^{17}$ CBP provides administrative data on employment and establishment counts for more than 900 industries for each county and year for the period we focus (see Eckert et al. 2019). The granularity of the industry classification available in the CBP allows us to focus on the legal sector employment (SIC 8100) and avoid measurement issues such as the ones that could come from aggregation with other services. Average wages for both skilled and unskilled legal workers are from the Bureau of Labor Statistics (BLS). ${ }^{18}$ County population data comes from United States Census Bureau's intercensal data. ${ }^{19}$

\subsection{Sample}

We follow the forum shopping literature (e.g., LoPucki and Kalin 2000), and focus our attention to the Court Competition Era, the period from 1991 to 1996 when Delaware emerged as a forum shopping destination, effectively creating a duopoly competition with New York (Section 2). Our sample consists of all U.S. counties with non-zero legal employment over the years 1991-1996. To avoid contamination effects for counties that receive forum shopped cases, our main sample omits counties from New York (NY) and Delaware (DE). This eases concerns that our results may be affected by counties receiving forum shopping cases, because these two states receive nearly all forum shopped cases (see Figure 2). ${ }^{20}$

\footnotetext{
${ }^{17}$ Source: Imputed CBP Data- Eckert et al. (2019).

${ }^{18}$ Source: Bureau of Labor Statistics Databases.

${ }^{19}$ Source: U.S. Census Bureau- Intercensal Datasets.

${ }^{20}$ Additionally we perform robustness checks to confirm that that our main results are not driven by this omission (see Section 4.3).
} 


\subsection{Bankruptcy Descriptive Statistics}

Table 1 reports descriptive statistics for bankruptcies and forum shopping in our sample. ${ }^{21}$ Our sample consists of approximately 544 bankruptcies, where roughly one-quarter of the cases are forum shopped. For the 451 county-year observations with at least one bankruptcy, we record on average 1.70 bankruptcy fillings and 0.47 forum shopped cases.

Table 1: Descriptive Statistics

\begin{tabular}{lcccc}
\hline & \multicolumn{2}{c}{ Full Sample } & \multicolumn{2}{c}{ County-Year with BR } \\
& Mean & Std. Dev. & Mean & Std. Dev. \\
\hline Bankruptcies & 0.048 & 0.397 & 1.703 & 1.673 \\
Forum Shopping & 0.013 & 0.155 & 0.470 & 0.800 \\
\hline Observations & 16064 & 451 & \\
\hline Note: County level descriptive statistics for number of bankruptcies and forum \\
shopped bankruptcies. Sources: Lopucki BRD, Compustat, CBP, U.S. Census \\
Bureau, BEA, SEC EDGAR. \\
Full Sample: All counties with non-zero legal employment during the period \\
1991-1996, not including counties from New York and Delaware. \\
County-Year with BR: All counties where at least one bankruptcy took \\
place during the period 1991-1996, not including counties from New York and \\
Delaware.
\end{tabular}

Figure 5 illustrates the distribution of forum shopping across SIC industry groups. The figure shows that both bankruptcy and forum shopping took places in virtually all industries. Similarly, Appendix B shows that the geographical distribution of bankruptcies (Figure 3) and forum shopping (Figure 4) is fairly well spread out across the U.S. with clusters of bankruptcies not surprisingly occurring in counties with major population centers.

\footnotetext{
${ }^{21}$ See Table 9 in Appendix A for an additional descriptive table that includes the controls and the dependent variable used in our main specification.
} 

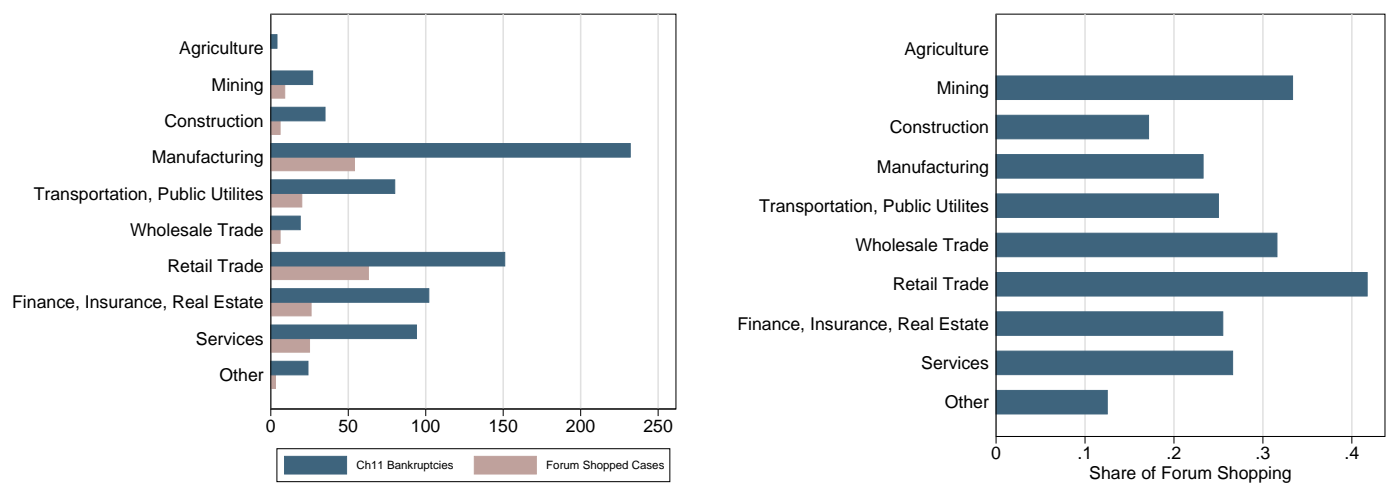

Figure 5: Bankruptcy and Forum Shopping by Industry - Number of Ch11 bankruptcies and forum shopped Ch11 Bankruptcies (left); share of Ch11 bankruptcies that are forum shopped by industry (right). Both graphs show cases from 1991 through 1996, omitting cases from New York and Delaware. Industry is defined by SIC division.

\subsection{Methodology}

To study the impact of Chapter 11 bankruptcy filings on the local legal sector, we estimate a linear regression model,

$$
\ln y_{c t}=\gamma_{B R} \times \text { bankruptcies }_{c t}+\beta X_{c t}+\eta_{c}+\delta_{d(c) t}+\varepsilon_{c t}
$$

$y_{c t}$ captures our main outcome of interest: the level of employment in the legal sector in county $c$ in year $t$. The treatment variable bankruptcies denotes the county-year bankruptcy shock. As our benchmark measure, we use the number of firms headquartered in county $c$ that have an active Chapter 11 filing in year $t$. This measure includes forum shopped cases.

The parameter $\gamma_{B R}$ is our key estimation target. We expect $\gamma_{B R}>0$ if bankruptcies generate a positive demand shock to local legal markets. As mentioned in the introduction, this is far from a foregone conclusion. It could be the case that bankruptcy filings do not increase local employment due to legal firms reassigning workers from other cases, hiring workers in other counties, or increasing the hours worked without hiring more workers, among other things.

To estimate $\gamma_{B R}$, we exploit identifying variation coming from Chapter 11 bankruptcies of large publicly traded firms. The bankruptcy decisions of these 
large corporations - usually multinational firms - are largely independent from fluctuations in the local economy (county) where they are headquartered, which absorb only a small fraction of their profits and revenues. As a result, these bankruptcies provide plausibly exogenous shocks to the local legal labor market. Section 3.5.1 corroborates this exogeneity assumption.

We account for other potential sources of variation in the level of legal employment with time-varying controls at the county level and fixed effects. The matrix $X_{c t}$ captures the additional time-varying controls, such as the log of county's population and the log of county's employment level in non-legal sectors in a given year. We expect both of these to be positively correlated with the level of legal sector employment. The county level fixed effects, $\eta_{c}$, captures county-specific time-invariant factors that affect the level of legal employment. District-year fixed effects, $\delta_{d(c) t}$, absorbs all time-varying variables at the district-year level that affect our outcome of interest. These time-varying factors include measures of the business cycle at the district level, as well as potential policy changes for particular district courts. After dropping counties from New York and Delaware, our sample is left with 85 judicial districts that subdivide the remaining states into between 1 and 4 parts. Accordingly, district-year fixed effects control for time-varying unobserved factors at the state level. Finally, $\varepsilon_{c t}$ is the usual error term.

To exploit forum shopping as an 'institutional placebo', we estimate the following augmented model

$\ln y_{c t}=\gamma_{B R} \times$ bankruptcies $_{c t}+\gamma_{F S} \times$ forum shopping st $+\beta X_{c t}+\eta_{c}+\delta_{d(c) t}+\varepsilon_{c t}$.

where $\gamma_{F S}$ captures the effect of forum shopping on our main outcome. For firms headquartered in county $c$ during year $t$, forum shopping counts $_{\text {coumber }}$

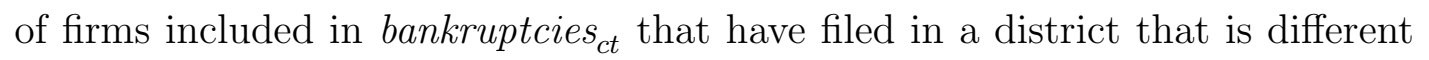
than the district where the firm's headquarters are located. ${ }^{22}$ Note that by

\footnotetext{
${ }^{22}$ To identify the local effect of bankruptcy, we need a clean geographical separation between the bankrupt's area and the court of filing. To do so, we define a forum-shopped case, as a bankruptcy case filed in a different district than the one where the firm is headquartered. The BRD database also considers in-district' forum shopping, which only account for
} 
construction $0 \leq$ forum shopping $_{c t} \leq$ bankruptcies $_{c t}$.

This specification has two objectives. The first goal is to test our identification strategy by verifying that $\gamma_{B R}$ effectively measures the impact of bankruptcies on local legal employment. If corporate bankruptcies are merely acting as a proxy for another determinant of demand for legal services (e.g., worker lawsuits, a spike in divorces, etc.), then the location of the filing should not affect our estimated results. However, if the estimated effect of forum shopping is negative and 'cancels out' the effect of the bankruptcy, then it seems plausible that our observed effect is a result of the bankruptcy filing itself. This first goal requires that the decision to forum shop is not systematically related to attributes of the local legal markets. For example, if firms forum shop due to high wages in the local legal sector, then forum shopping would not provide the required exogenous variation to work as an 'institutional placebo'. In Section 3.5.2, we provide institutional background and relevant literature to argue why we do not expect this to be the case. In addition, we perform a regression analysis to corroborate this exogeneity assumption.

The second goal is to improve the measurement of the effect of bankruptcy filings on local legal employment, by allowing regular and forum shopped filings to have a differential impact.

\subsection{Identification Challenges}

In this section, we address potential concerns over two key identifying assumptions: (i) exogeneity of bankruptcy shocks to changes in local county conditions; (ii) exogeneity of firms' choice to forum shop to local legal market conditions.

\subsubsection{Bankruptcy Shocks Exogenous to Local Conditions}

Publicly traded firms are large (often multinational) firms with customers across the U.S. and around the world. Accordingly, the share of profits that directly depends on the local conditions of their headquarter county is very small and is unlikely to have any impact on their decision to file for bankruptcy. Just as economic fluctuations in Rochester, New York played little to no role in

a handful of cases (11 out 88). 
Kodak's decision to file for bankruptcy, bankruptcy decisions of other publicly traded firms in our sample are plausibly decoupled from their local economy. They are beholden to fluctuations in demand on a much larger scale than their local county. As a result, Chapter 11 bankruptcies of publicly traded firms can plausibly provide identifying variation to estimate the effect of demand shocks on local legal markets services.

Table 2: Regressions for number of bankruptcies on changes in county conditions.

\begin{tabular}{lccccc}
\hline & $(1)$ & $(2)$ & $(3)$ & $(4)$ & $(5)$ \\
\hline$\% \Delta$ (County Population) & 0.221 & 0.224 & 0.273 & 0.233 & 0.288 \\
& $(0.209)$ & $(0.210)$ & $(0.204)$ & $(0.212)$ & $(0.207)$ \\
$\% \Delta$ (Emp Non-Legal) & & -0.00402 & & & -0.00356 \\
& & $(0.00880)$ & & & $(0.00927)$ \\
$\% \Delta$ (Non-Legal Establishments) & & & 0.00206 & & 0.00601 \\
& & & $(0.0188)$ & & $(0.0200)$ \\
Unemployment Rate & & & & 0.00134 & 0.00144 \\
& & & & $(0.00171)$ & $(0.00172)$ \\
\hline County FE & Yes & Yes & Yes & Yes & Yes \\
District-Year FE & Yes & Yes & Yes & Yes & Yes \\
R-Squared & 0.772 & 0.772 & 0.774 & 0.772 & 0.774 \\
Observations & 15931 & 15931 & 15925 & 15931 & 15925 \\
\hline Stanlard ers & & & & & \\
\hline
\end{tabular}

Standard errors clustered at county level in parentheses

${ }^{*} p<0.1,{ }^{* *} p<0.05,{ }^{* * *} p<0.01$

Note: OLS regression estimates of number of bankruptcies in a county year on: (i) Treatment: NA; (ii) Fixed Effects: county and district-year, where district is one of 90 judicial districts; (iii) Controls: county-year unemployment rate, and county-year change from previous year in the following- log of population, log of employment in non-legal sectors, log of the number of establishments in non-legal sectors. Sample: All U.S. counties with non-zero legal employment, omitting Delaware and New York. Period: 1991-1996. Sources: Lopucki BRD, Compustat, CBP, U.S. Census Bureau, BEA, SEC EDGAR, BLS.

To corroborate this exogeneity assumption, we empirically evaluate whether bankruptcy filings of publicly traded firms are indeed uncorrelated with fluctuations in their headquarter county's socio-economic conditions. To do so, we regress the number of county-year bankruptcies on several county-year economic attributes that can be correlated with local county conditions, such as unemployment rate at the county level, changes in county population, entry and exit of firms at the county level, and changes in employment level outside of the legal sector. Table 2 shows evidence that changes in county population, employment, 
number of establishments in non-legal sectors, and even unemployment do not predict bankruptcy filings. These results suggest that any observed changes in local legal employment when a county experiences a bankruptcy shock is unlikely to have been caused by confounding factors related to changes in county conditions.

This plausible exogeneity to confounding factors is further bolstered by a battery of placebo tests (Section 4.1.1), robustness checks (Section 4.3), and by exploiting forum shopping as an 'institutional placebo' (Section 4.2).

\subsubsection{Forum Shopping Exogenous to Local Conditions}

To exploit forum shopping for identification, we need firms choice to forum shop to be conditionally exogenous with respect to county attributes which affect legal sector employment. We support this claim in two ways. First, we refer to the relevant literature to illustrate how this exogeneity assumption has institutional roots in Chapter 11 bankruptcy practices. Then, we empirically evaluate whether firms' decisions to forum shop are correlated with local legal labor market attributes, conditional on firms' size, degree of financial distress and fixed effects.

Much of the literature relating to forum shopping during the Court Competition Era contends that the primary incentive for firms to forum shop was to find "debtor-friendly" courts (e.g. LoPucki 2005; Gennaioli and Rossi 2010). For instance, Eisenberg and LoPucki (1999) gives evidence against alternative incentives for forum shopping and ascertains that "the persistence of forum shopping demonstrates the importance of judges to litigants".

Furthermore, the exogeneity of the firm's forum shopping decision is consistent with their modus operandi for hiring bankruptcy experts. When a large publicly traded firm files for Chapter 11 bankruptcy, regardless of where they file, it is typical to hire a handful of legal experts from large hubs such as New York to develop a reorganization plan (LoPucki 2005). Therefore, it is unlikely that firms chose to forum shop because the legal industry in their area lacked sufficient expertise. The pattern of forum shopping during the Court Competition Era suggests that the quality of the legal industry in the filing court's 
area was not a major factor in the firm's venue choice. Indeed, when Delaware emerged as a hot bed for forum shopping in the early 1990's, it was considered to be a "sleepy, backwater bankruptcy district virtually devoid of bankruptcy professionals" (Eisenberg and LoPucki 1999).

Table 3: Regressions for firms' choice to forum shop on firm and county characteristics.

\begin{tabular}{|c|c|c|c|c|c|}
\hline & (1) & $(2)$ & $(3)$ & $(4)$ & $(5)$ \\
\hline $\ln$ (Firm Assets) & $\begin{array}{c}0.0642^{* * *} \\
(0.0189)\end{array}$ & & $\begin{array}{c}0.0642^{* * *} \\
(0.0195)\end{array}$ & $\begin{array}{c}0.0748^{* * *} \\
(0.0217)\end{array}$ & $\begin{array}{c}0.0798^{* * *} \\
(0.0289)\end{array}$ \\
\hline Firm Leverage & $\begin{array}{c}0.00179 \\
(0.00115)\end{array}$ & & $\begin{array}{l}0.00214^{*} \\
(0.00124)\end{array}$ & $\begin{array}{l}0.00265^{*} \\
(0.00135)\end{array}$ & $\begin{array}{l}-0.000544 \\
(0.00334)\end{array}$ \\
\hline $\ln$ (Firm Employment) & $\begin{array}{l}0.00496 \\
(0.0174)\end{array}$ & & $\begin{array}{l}0.00614 \\
(0.0179)\end{array}$ & $\begin{array}{c}-0.00831 \\
(0.0199)\end{array}$ & $\begin{array}{l}-0.0182 \\
(0.0307)\end{array}$ \\
\hline $\ln$ (County Legal Sector Emp) & & $\begin{array}{l}-0.0163 \\
(0.0495)\end{array}$ & $\begin{array}{l}-0.0419 \\
(0.0541)\end{array}$ & $\begin{array}{l}-0.0361 \\
(0.0539)\end{array}$ & $\begin{array}{l}-0.111 \\
(0.104)\end{array}$ \\
\hline $\ln$ (County Legal Sector Avg Wage) & & $\begin{array}{c}-0.00843 \\
(0.144)\end{array}$ & $\begin{array}{c}0.100 \\
(0.155)\end{array}$ & $\begin{array}{c}0.133 \\
(0.157)\end{array}$ & $\begin{array}{c}0.344 \\
(0.447)\end{array}$ \\
\hline $\ln$ (County Population) & & $\begin{array}{c}0.0340 \\
(0.0544)\end{array}$ & $\begin{array}{c}0.0430 \\
(0.0579)\end{array}$ & $\begin{array}{c}0.0251 \\
(0.0586)\end{array}$ & $\begin{array}{l}0.0524 \\
(0.116)\end{array}$ \\
\hline $\begin{array}{l}\text { Fixed Effects } \\
\text { Year } \\
\text { Industry } \\
\text { District-Year }\end{array}$ & $\begin{array}{l}\text { Yes } \\
\text { No } \\
\text { No }\end{array}$ & $\begin{array}{l}\text { Yes } \\
\text { No } \\
\text { No }\end{array}$ & $\begin{array}{l}\text { Yes } \\
\text { No } \\
\text { No }\end{array}$ & $\begin{array}{l}\text { Yes } \\
\text { Yes } \\
\text { No }\end{array}$ & $\begin{array}{l}\text { No } \\
\text { Yes } \\
\text { Yes }\end{array}$ \\
\hline $\begin{array}{l}\text { R-Squared } \\
\text { Observations }\end{array}$ & $\begin{array}{c}0.112 \\
351\end{array}$ & $\begin{array}{c}0.0231 \\
393\end{array}$ & $\begin{array}{c}0.117 \\
344\end{array}$ & $\begin{array}{c}0.143 \\
343\end{array}$ & $\begin{array}{c}0.464 \\
251\end{array}$ \\
\hline \multicolumn{6}{|c|}{$\begin{array}{l}\text { Standard errors clustered at firm level in parentheses } \\
{ }^{*} p<0.1,{ }^{* *} p<0.05,{ }^{* * *} p<0.01\end{array}$} \\
\hline \multicolumn{6}{|c|}{$\begin{array}{l}\text { Note: OLS regression estimates of whether a firm filing for Ch11 bankruptcy chose to FS on: (i) Treatment: } \\
\text { NA; (ii) Fixed Effects: year, industry, and district-year; (iii) Controls: log of firm's total assets and employ- } \\
\text { ment, firm's leverage, log of county-year employment in legal sector, log of county-year average wage in legal } \\
\text { sector and log of county-year population. Here we use Leverage = Liabilities/Assets. Sample: County year ob- }- \text { sant } \\
\text { servations of publicly traded firms who filed for Ch11 bankruptcy. Period: 1991-1996. Sources: Lopucki BRD, } \\
\text { Compustat, CBP, U.S. Census Bureau, BEA, SEC EDGAR, BLS. }\end{array}$} \\
\hline
\end{tabular}

To provide empirical support for these institutional arguments, we regress an indicator of whether or not a firm forum shopped on firms' characteristics and local legal sector labor markets characteristics in the year of filing. Since only firms that filed for bankruptcy can decide to forum shop, we restrict our sample to bankrupt firms. To measure firms' size we use total assets and total employment. We then include leverage to control for the firms' degree of finan- 
cial distress. We use legal sector employment, average wage in the legal sector and county population as county characteristics.

Table 3 presents the results of these regressions with a variety of fixed effects. Across all specifications, we find no evidence that a firm's propensity to forum shop is influenced by any of the local legal sector characteristics. Column (2) shows this finding holds even when nothing is controlled for besides county characteristics and year fixed effects. We find that only the total assets of the firm at the time of bankruptcy are associated with a meaningfully significant increase in the likelihood of a firm to forum shop, indicating that firm size may play a role.

\section{Bankruptcy Shocks and Legal Labor Markets}

This section estimates the effect of bankruptcy shocks on local legal labor markets. A large publicly listed firm bankruptcy is a significant demand shock to legal services. Average professional fees for one of these bankruptcies amount to $\$ 82$ million in 2021 dollars in our Lopucki BRD sample. While some of these fees may go to bankruptcy experts located in hubs like New York (LoPucki 2005), much of the fees go to legal services performed where the bankruptcy court is located. These services are carried in locus by teams of legal clerks and paralegals certified to practice in the bankruptcy court area, familiar with local bankruptcy practices, and able to attend proceedings and process paperwork at the courthouse. Freedman (2005) estimates that it takes upwards of 1.3 non-lawyer employees for every lawyer.

Section 4.1 estimates the impact of bankruptcies on county legal employment. Section 4.2 illustrates how results change when we consider forum shopping. Section 4.3 demonstrates the robustness of our results to additional considerations. Finally Section 4.4 builds on the previous results to estimate the potential employment and wage gains lost to New York and Delaware because of forum shopping.

\subsection{Bankruptcy Shocks and Legal Employment}

We use our benchmark model (1) to estimate the effect of bankruptcy shocks on legal employment. Table 4 reports estimates obtained by regressing the county- 
year level of legal employment on the number of bankruptcies and county-year controls. These results indicate that a bankruptcy filing from a firm headquartered in the county is associated with a statistically and economically significant increase in the level of legal employment in that locale. From left to right, each column shows the estimates for gradually more demanding fixed effects along the geographical and time dimension. ${ }^{23}$ The impact of one bankruptcy on legal employment is robust and stable across the different specifications, varying between $0.070 \%$ and $0.086 \%$.

Table 4: Employment Level Regressions

\begin{tabular}{|c|c|c|c|c|c|c|}
\hline & $(1)$ & $(2)$ & $(3)$ & $(4)$ & $(5)$ & $(6)$ \\
\hline Bankruptcies & $\begin{array}{c}0.00793^{* * *} \\
(0.00280)\end{array}$ & $\begin{array}{c}0.00830^{* * *} \\
(0.00287)\end{array}$ & $\begin{array}{l}0.00720^{* *} \\
(0.00330)\end{array}$ & $\begin{array}{l}0.00768^{* *} \\
(0.00335)\end{array}$ & $\begin{array}{l}0.00702^{* *} \\
(0.00283)\end{array}$ & $\begin{array}{c}0.00859^{* * *} \\
(0.00284)\end{array}$ \\
\hline $\ln ($ County Population) & $\begin{array}{c}0.797^{* * *} \\
(0.115)\end{array}$ & $\begin{array}{c}0.750^{* * *} \\
(0.125)\end{array}$ & $\begin{array}{c}0.726^{* * *} \\
(0.137)\end{array}$ & $\begin{array}{c}0.715^{* * *} \\
(0.144)\end{array}$ & $\begin{array}{c}0.651^{* * *} \\
(0.134)\end{array}$ & $\begin{array}{c}0.694^{* * *} \\
(0.134)\end{array}$ \\
\hline $\ln ($ Emp Non-Legal) & $\begin{array}{l}0.181^{* * *} \\
(0.0418)\end{array}$ & $\begin{array}{l}0.166^{* * *} \\
(0.0468)\end{array}$ & $\begin{array}{l}0.167^{* * *} \\
(0.0481)\end{array}$ & $\begin{array}{l}0.170^{* * *} \\
(0.0489)\end{array}$ & $\begin{array}{l}0.174^{* * *} \\
(0.0479)\end{array}$ & $\begin{array}{l}0.170^{* * *} \\
(0.0474)\end{array}$ \\
\hline $\begin{array}{l}\text { Fixed Effects } \\
\text { County } \\
\text { Year } \\
\text { Region-Year } \\
\text { Division-Year } \\
\text { State-Year } \\
\text { District-Year }\end{array}$ & $\begin{array}{l}\text { Yes } \\
\text { No } \\
\text { No } \\
\text { No } \\
\text { No } \\
\text { No }\end{array}$ & $\begin{array}{l}\text { Yes } \\
\text { Yes } \\
\text { No } \\
\text { No } \\
\text { No } \\
\text { No }\end{array}$ & $\begin{array}{l}\text { Yes } \\
\text { No } \\
\text { Yes } \\
\text { No } \\
\text { No } \\
\text { No }\end{array}$ & $\begin{array}{l}\text { Yes } \\
\text { No } \\
\text { No } \\
\text { Yes } \\
\text { No } \\
\text { No }\end{array}$ & $\begin{array}{l}\text { Yes } \\
\text { No } \\
\text { No } \\
\text { No } \\
\text { Yes } \\
\text { No }\end{array}$ & $\begin{array}{l}\text { Yes } \\
\text { No } \\
\text { No } \\
\text { No } \\
\text { No } \\
\text { Yes }\end{array}$ \\
\hline $\begin{array}{l}\text { R-Squared } \\
\text { Observations }\end{array}$ & $\begin{array}{c}0.984 \\
15963\end{array}$ & $\begin{array}{c}0.984 \\
15963\end{array}$ & $\begin{array}{l}0.984 \\
15963\end{array}$ & $\begin{array}{l}0.984 \\
15931\end{array}$ & $\begin{array}{c}0.984 \\
15963\end{array}$ & $\begin{array}{c}0.984 \\
15963\end{array}$ \\
\hline \multicolumn{7}{|c|}{$\begin{array}{l}\text { Standard errors clustered at county level in parentheses } \\
{ }^{*} p<0.1,{ }^{* *} p<0.05,{ }^{* * *} p<0.01 \\
\text { Note: OLS regression estimates of log Legal Employment on: (i) Treatment: number of bankruptcies; (ii) Fixed Ef- } \\
\text { fects: county; county and year; county and region-year, where region is one of } 4 \text { Census Bureau-designated regions; } \\
\text { county and division-year, where division is one of } 9 \text { Census Bureau-designated divisions; county and state-year; } \\
\text { county and district-year, where district is one of } 90 \text { judicial districts; (iii) Controls: log of county-year population, } \\
\text { log of county-year employment in all non-legal sectors. Sample: All U.S. counties with non-zero legal employment, } \\
\text { omitting Delaware and New York. Period: 1991-1996. Sources: Lopucki BRD, Compustat, CBP, U.S. Census } \\
\text { Bureau, BEA, SEC EDGAR. }\end{array}$} \\
\hline
\end{tabular}

Our preferred specification is the most demanding and controls for county and district-year fixed effects (Table 4 Column (6)). These fixed effects absorb

\footnotetext{
${ }^{23}$ We follow the Census Bureau definition of the region and use 4 categories: Northeast, Midwest, South and West. In the case of Column (6), we introduce judicial district-year fixed effects. The U.S. states are divided into 90 judicial districts that subdivide the states into 1-4 parts. Hence, this is akin to controlling for time-varying within-state factors.
} 
all determinants of legal employment level that are constant at the county level and absorb all time-varying determinants at the district level, including district GDP, unemployment rate, as well as any other district level measure of the business condition. Under this specification, each active bankruptcy filing is associated with a $0.77 \%$ increase in county legal employment. Hence, using the figures from Table 1, counties with at least one ongoing bankruptcy are associated with a $1.3 \%$ increase in legal employment. Using BLS data on average wages these job losses come out to roughly $\$ 5$ million worth of employment annually for the affected county.

\subsubsection{Placebo Tests}

We perform several placebo tests to evaluate whether there were differences in the local legal employment level in the counties affected by bankruptcies before the filings took place. To do this, we lag the variable that captures the number of bankruptcies. More specifically, we use three alternative lag structures: one, two, and three years before bankruptcies actually occurred. Additionally, we combine all three measures in the same specification.

Table 5 shows that none of the lagged bankruptcy measures are associated with a significant change in legal employment and the estimated coefficients shrink by an order of magnitude compared to the contemporaneous version. Hence, there are no significant differences in the level of local legal employment for the counties affected by bankruptcies before the bankruptcies actually occur. These results provide further evidence for our claim that bankruptcy filings are associated with a positive impact on the local legal employment level. See Appendix $\mathrm{C}$ for additional placebo tests using alternative treatment measures.

\subsection{Forum Shopping}

From 1991 through 1996, the intense competition between Delaware and New York ignited a surge in forum shopping cases all around the US (see Section 2), as filing firms flocked to these two magnet districts. For these forum shopping firms, the distance between where the firms are located and where they file is considerably larger. In the Lopucki BRD sample, the average distance from 
Table 5: Employment Level Regressions with lags for bankruptcy shock.

\begin{tabular}{lcccc}
\hline & $(1)$ & $(2)$ & $(3)$ & $(4)$ \\
\hline L1.Bankruptcies & 0.00231 & & & 0.00256 \\
& $(0.00312)$ & & & $(0.00312)$ \\
L2.Bankruptcies & & 0.000304 & & -0.000529 \\
& & $(0.00280)$ & & $(0.00256)$ \\
L3.Bankruptcies & & -0.000118 & 0.000549 \\
& & & $(0.00315)$ & $(0.00335)$ \\
$\ln ($ County Population) & $0.715^{* * *}$ & $0.716^{* * *}$ & $0.715^{* * *}$ & $0.715^{* * *}$ \\
& $(0.144)$ & $(0.144)$ & $(0.144)$ & $(0.144)$ \\
$\ln ($ Emp Non-Legal) & $0.170^{* * *}$ & $0.170^{* * *}$ & $0.171^{* * *}$ & $0.171^{* * *}$ \\
& $(0.0489)$ & $(0.0489)$ & $(0.0490)$ & $(0.0490)$ \\
\hline County FE & Yes & Yes & Yes & Yes \\
District-Year FE & Yes & Yes & Yes & Yes \\
R-Squared & 0.984 & 0.984 & 0.984 & 0.984 \\
Observations & 15931 & 15931 & 15930 & 15930 \\
\hline Standard
\end{tabular}

Standard errors clustered at county level in parentheses

${ }^{*} p<0.1,{ }^{* *} p<0.05,{ }^{* * *} p<0.01$

Note: OLS regression estimates of log Legal Employment on: (i) Treatment: number of bankruptcies lagged one, two, or three years; (ii) Fixed Effects: county and district-year, where district is one of 90 judicial districts; (iii) Controls: log of county-year population, log of county-year employment in all non-legal sectors. Sample: All U.S. counties with non-zero legal employment, omitting Delaware and New York. Period: 1991-1996. Sources: Lopucki BRD, Compustat, CBP, U.S. Census Bureau, BEA, SEC EDGAR.

firm headquarters to the court of filing for forum shopped cases was 766.1 miles from the firms headquarters, compared to just 18.9 miles for non-forum shopped cases. As a result, these bankruptcy cases should not trigger the usual spike in demand for legal services in the firms local area, and therefore should not affect the level of local legal employment.

To verify this conjecture Table 6 uses model specification (2), which controls for both bankruptcy and forum shopped filings. ${ }^{24}$ Column (2) shows that for a county-year observation, the estimated effect of the number of bankruptcies on the legal sector employment is $1 \%$, a notable increase from the previous

\footnotetext{
${ }^{24} \mathrm{We}$ also estimate alternative versions of Table 6 where we use different sets of fixed effects. These tables are reported in Appendix D and in all cases they confirm our results.
} 
Table 6: Employment Level Regressions

\begin{tabular}{lccc}
\hline & $(1)$ & $(2)$ & $(3)$ \\
\hline Bankruptcies & $0.00768^{* *}$ & $0.0100^{* * *}$ & \\
& $(0.00335)$ & $(0.00373)$ & \\
Non-FS Bankruptcies & & & $0.0100^{* * *}$ \\
& & & $(0.00373)$ \\
Forum Shopping & & $-0.0111^{*}$ & -0.00108 \\
& & $(0.00637)$ & $(0.00564)$ \\
\hline County FE & Yes & Yes & Yes \\
District-Year FE & Yes & Yes & Yes \\
R-Squared & 0.984 & 0.984 & 0.984 \\
Observations & 15931 & 15931 & 15931 \\
\hline
\end{tabular}

Standard errors clustered at county level in parentheses

${ }^{*} p<0.1,{ }^{* *} p<0.05,{ }^{* * *} p<0.01$

Note: OLS regression estimates of log Legal Employment on: (i) Treatment: number of bankruptcies, number of forum shopped bankruptcies, number of non-forum shopped bankruptcies; (ii) Fixed Effects: county and district-year, where district is one of 90 judicial districts; (iii) Controls: log of county-year population, log of county-year employment in all non-legal sectors. Sample: All U.S. counties with non-zero legal employment, omitting Delaware and New York. Period: 1991-1996. Sources: Lopucki BRD, Compustat, CBP, U.S. Census Bureau, BEA, SEC EDGAR.

specification that did not control for forum shopping (0.7\%). In addition, forum shopping has a negative impact of a similar magnitude, dampening the effect of bankruptcies not filed locally. Column (3) tests the net effect of a forum shopped bankruptcy filing on local legal employment by using an alternative measure of bankruptcy that only includes bankruptcies filed locally (non-forum shopped). As expected, this shows that a forum shopped bankruptcy case does not have a statistically, or economically, significant effect on local legal employment ($0.1 \%)$.

As discussed in Section 3.4, the forum shopping channel also plays a crucial role for identification, as it provides an institutional mechanism to corroborate our interpretation of $\gamma_{1}$. The null effect of forum shopped cases implies that the bankruptcy filing itself is causing the observed impact on legal employment, and not some other confounding factor associated with these bankruptcies. Section 
3.5.2 justifies the validity of using forum shopping as an institutional placebo.

Finally, the average level of treatment for treated counties is 1.70 bankruptcy filings, 0.47 of which are forum shopped (Table 1). Accordingly, the estimates from Column (2) imply that the expected increase in legal employment is roughly $1.2 \%$ among treated county-year observations.

\subsection{Robustness Checks}

This section reports several robustness exercises aimed at easing concerns regarding our empirical results. We grouped these robustness exercises in three broad categories: (i) sample definition, (ii) controls included, and (iii) key variable measurement. In all cases our main results are unchanged.

\subsubsection{Sample}

Our results are robust to adjusting the sample considered in the regression analysis along several dimensions. We first include New York and Delaware counties. Second, we drop 1991 from our benchmark sample period. Third, we narrow our sample to more relevant subsets of counties: counties where at least one publicly traded firm is located at any time between 1991 and 1996, or counties with at least one publicly traded firm undergoing bankruptcy during our sample period. Fourth, we limit the sample to counties where district courts are located. Finally, we extend our sample to cover the period 1991-2001 for specification (1).

Include New York and Delaware counties: Our main sample drops counties from New York and Delaware due to the fact that these magnet districts attracted most of the forum shopping cases during the Court Competition Era (which may have impacted their level of legal employment). To evaluate if this restriction is affecting our results, we re-perform our analysis on an augmented sample that includes New York and Delaware counties. Results are reported in Columns (1) and (2) of Table 13. As before, we find that each bankruptcy filing is associated with an increase in local legal employment of almost $1 \%$ and that forum-shopping nullifies this effect.

Restricted Sample Period: Our baseline sample period 1991-1996 can 
be considered largely free of recessions on an aggregate level. However, it could be argued that the beginning of our sample period coincides with the ending of the 1991 recession (first quarter 1991, Hamilton 2020). To ease concerns about this potential contamination, we drop the year 1991. Columns (3) and (4) of Table 13 show that our estimates are largely unaffected by this change.

More Relevant Comparison Groups: One potential issue with our sample is that by including all counties where legal employment is non-zero we also include in our control group counties that could not feasibly experience a bankruptcy shock, as no publicly traded firms were located there. We address these concerns by replicating our baseline results with samples that have been restricted to only include counties that could plausibly receive treatment.

First, we restrict our estimation sample to counties with at least one publicly traded company located therein at any point in the period from 1991 through 1996. This restriction significantly reduces our estimation sample to approximately one-third of the observations in our baseline sample. Nonetheless, results in Columns (1) and (2) of Table 14 confirm all our main findings.

To further make our sample of counties comparable, we restrict our sample to counties that experienced a bankruptcy at some point in our sample period. This drastically reduces the sample size to 354 county-year observations. Columns (3) and (4) of Table 14 show our main findings still hold.

Counties with Bankruptcy Courts: Our sample may include a small number of cases where a firm does not forum shop, but nonetheless is still located a substantial distance from their local court. If this is the case, the effect of the bankruptcy may not actually occur in the county the firm is located in, or at the very least could be reduced. To address these potential concerns, we run our benchmark regressions on a sample that only includes counties where a bankruptcy court is located. While there are 90 judicial districts that handle bankruptcies, several of those districts have multiple physical court locations. As a result, there are approximately 200 counties that contain a bankruptcy court. Despite greatly reducing the sample size (1074 observations), Columns (5) and (6) of Table 14 show that our results still hold. ${ }^{25}$

\footnotetext{
${ }^{25}$ Note that district-year fixed effects are not used because of perfect collinearity for many
} 
Extended Sample Period: To explore whether our results hold when we consider a longer period, we rerun our benchmark results from Table 4 for the period 1991-2001. Importantly, these years make up the post-war era's longest business cycle expansion prior to the 2008 financial crisis. The results in Table 15 supports our main finding that bankruptcy filings are associated with an increase in local legal employment.

\subsubsection{Controls}

In our benchmark specification, we include county level controls for the log of population and the log of the number of employees outside of the legal sector. In this subsection, we extend our set of controls by lagging the controls and by including new time-varying county variables.

Lagged Controls: We run our regressions where controls are lagged one year to avoid potential impact of bankruptcies on the control variables. The results of this estimation are presented in Columns (1) and (2) of Table 16 and they confirm our findings. Note that this approach also avoids potential indirect effects of bankruptcies on the level of employment outside of the legal sector.

Business Cycle: Another possible concern is that our estimates may be sensitive to macroeconomic conditions. Previously we have already addressed this concern in two ways. First, our preferred specification includes district-year fixed effects that fully control for time-varying aggregate shocks at the district and national level. Second, in Table 13 we drop the year 1991 since it overlaps with the end of a recession.

Notwithstanding, here we also incorporate additional time-varying controls that could be expected to be correlated with county-level business-cycle fluctuations, such as the county-year unemployment rate (from the BLS), and the percent change in the number of establishments outside the legal sector (from the CBP). Again, our findings are robust to these alternative specifications. These results can be found in Columns (3) through (6) of Table 16.

districts that have only 1 bankruptcy court. State-year then becomes our preferred fixed effect. 


\subsubsection{Measurement}

In this section, we explore the robustness of our main results to alternative measurements of bankruptcy, forum shopped bankruptcies, and employment levels in the legal sector and non-legal sector. In all cases, our findings are aligned with our priors.

Binary measurement: Columns (1) and (2) of Table 17 show estimates when we replace the bankruptcy and forum shopping count variables with their respective dummies. Our main findings still hold, albeit with reduced significance. This result is expected due to the fact that these measurements for bankruptcy and forum shopping are less precise compared to the benchmark count variables.

Value-Weighted Measurement: In our benchmark regressions, we use an issuer-weighted measure of bankruptcy and forum shopping, which simply counts the number of bankruptcy cases. This overlooks potential heterogeneity in the impact from bankruptcy shocks of larger versus smaller firms. To explore this, we include regressions where bankruptcy and form shopping are measured by the amount of assets the company had at the time of filing for bankruptcy. Columns (3) and (4) of Table 17 present these results and confirm our findings for both bankruptcy and forum shopping.

Spillover Effects: To address the potential mismeasurement of bankruptcy shocks due to spillover effects, we run an additional specification which controls for potential spillover from nearby bankruptcies. To do this, we create a measure of the number of bankruptcy filings in counties that are directly adjacent to county $c$ in year $t$. As shown in Columns (1) and (2) of Table 18, we find no evidence that bankruptcies in adjacent counties have a meaningful impact on local legal employment.

Alternative Data Source: To further verify the validity of our results, we replicate our findings by constructing the employment variables from an alternative data source. Specifically, the dependent variable for legal employment, as well as the control for non-legal employment, are constructed using data from the Bureau of Labor Statistics (BLS) rather than CBP. The results from Columns (3) and (4) of Table 18 demonstrate that even with the less complete 
BLS data we still observe a significant and positive effect from bankruptcies that is canceled out by forum shopping.

\subsection{Potential Employment Gains Lost to NY and DE}

So far, our analysis has shown that bankruptcies of publicly listed firms boost the demand of local legal services (Section 4.1), but only when cases are not forum shopped (Section 4.2). Thus, forum shopping is effectively allowing distressed firms to import bankruptcy legal services from one of the two magnet districts: the Delaware and Southern District of New York (NYDE). This section builds of our previous results and uses the estimated effect of bankruptcy and forum shopping from Column (2) in Table 6 to quantify the unrealized local legal markets gains lost due to firms forum shopping to New York and Delaware. $^{26}$
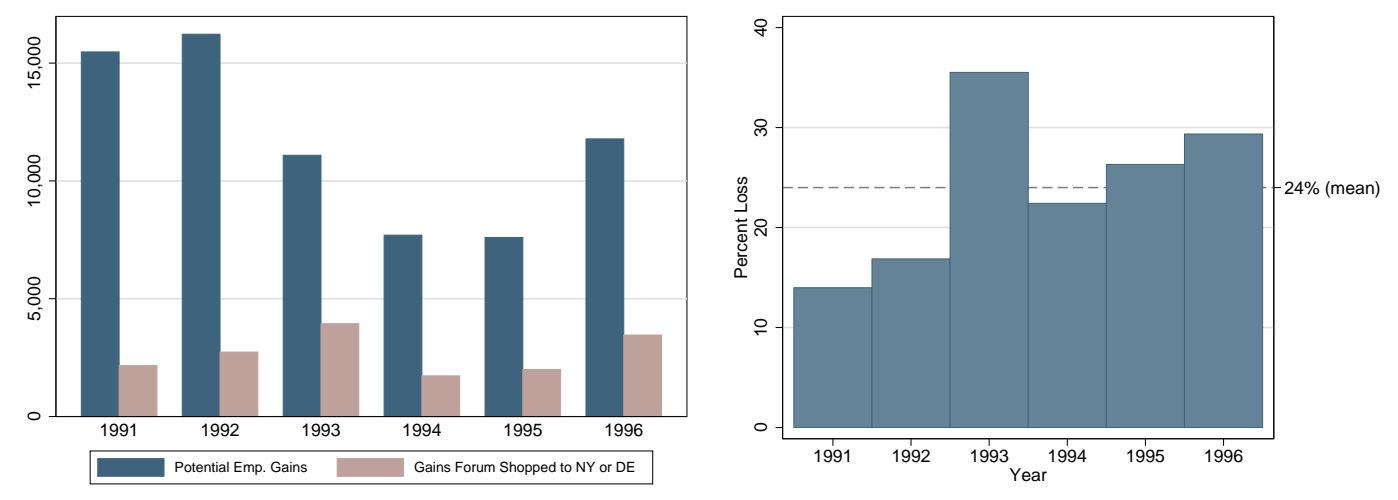

Figure 6: Expected Employment Gains Lost to NY and DE -

(left) Comparison of the total predicted potential legal employment gains from Ch11 bankruptcies and the amount of those gains lost to either New York or Delaware via forum shopping.

(right) The percentage of predicted potential legal employment gains from Ch11 bankruptcy unrealized due to forum shopping to New York or Delaware.

We start by estimating the predicted potential gains from bankruptcy for each county-year observation if all bankruptcies forum shopped to NYDE had instead been filed locally. To do this, we use the estimated impact of a bankruptcy

\footnotetext{
${ }^{26}$ Table 12 estimates the effect of bankruptcies and forum shopping when only shopping to NYDE is considered. These results are nearly identical to those from Table 6 verifying that the estimated effects do not change when only forum shopping to NYDE is considered.
} 
to calculate the total expected increase in legal employment from bankruptcies that were filed locally and the bankruptcies filed in NYDE. Next, we use the estimated impact of forum shopping to calculate the amount of these predicted potential gains that are lost to NYDE. Finally, we aggregate these potential gains and losses to show the total amount of potential employment gains being exported to New York and Delaware each year.

Figure 6 shows the extent to which potential gains from bankruptcies are being shopped away to New York and Delaware. These losses are considerable. Each year, an average of roughly 2,700 jobs, or $24 \%$ of potential gains, are lost from communities affected by major bankruptcies to New York and Delaware. Over the court competition era, this adds up to $\$ 1.63$ billion in wages in 2021 dollars (\$876 million nominally). To put this number in context, Criscuolo et al. (2019) estimate that for government investment in place-based job policies in the U.S. the cost per job created ranges between $\$ 23,000$ and $\$ 78,000$ in 2021 dollars (\$18,000 and $\$ 63,000$ in 2010 dollars). Accordingly, the cost to create those 2,700 lost jobs would be between $\$ 62$ and $\$ 211$ million in 2021 dollars. This back of the envelope calculation indicates that forum shopping may be the source of economically significant costs to local communities, so far unaccounted for by the current policy debate.

\section{A Model of Legal Services Labor Markets}

This section specializes a model with skilled and unskilled workers (e.g. Acemoglu 2002; Acemoglu and Autor 2011; Bowlus et al. 2017) to capture the impact of bankruptcy shocks on local legal labor markets. Our theoretical framework closely follows Notowidigdo (2020). We consider a dynamic partial equilibrium model of the local legal sector. The economy is populated by a mass of heterogeneous households and a representative firm that produces legal services. Households differ in their labor productivity: skilled and unskilled. Skilled workers can be thought of as lawyers, who require an extremely large investment in training before they can work. Whereas unskilled workers can be thought of as para-legals, law clerks, and other legal sector employees who re-

quire considerably less upfront costs in training relative to skilled workers. The 
representative firm hires skilled and unskilled workers to produce legal services (the numeraire). The demand for legal services is exogenous. Labor markets are competitive.

\subsection{Labor Demand}

For county $c$ in each period $t$ a profit-maximizing representative firm hires skilled $\left(n_{c, t}^{s}\right)$ and unskilled $\left(n_{c, t}^{u}\right)$ workers to produce legal services $(L)$ according to the following constant elasticity of substitution production function:

$$
L_{c, t}=\theta_{c, t}\left[(1-\lambda)\left(n_{c, t}^{u}\right)^{\zeta}+\lambda\left(A n_{c, t}^{s}\right)^{\zeta}\right]^{\frac{\alpha}{\zeta}}
$$

where $\delta \equiv 1 /(1-\zeta)$ is the elasticity of substitution between the input factors, $A$ measures the relative efficiency of skilled workers, $\alpha$ is the returns to scale, and $\lambda$ is a share parameter.

Similar to Notowidigdo (2020), $\theta_{c, t}$ is a measure of county level labor demand in the legal service sector. This follows in a similar vein to Bai, Rios-Rull, and Storesletten (2012), where shocks to demand enter the model as 'productivity shocks' through $\theta_{c, t}$. In doing so, the model takes into account the fact that even for fixed inputs the level of production will depend on the amount of demand for that good, and in turn the level of demand for the inputs. Following our findings in Section 4, we use Chapter 11 bankruptcy shocks as a source of plausibly exogenous variation in $\theta_{c, t}$.

Markets are competitive and factors receive their marginal product as wages

$$
\begin{gathered}
w_{c, t}^{s}=\alpha \theta_{c, t}\left[(1-\lambda)\left(n_{c, t}^{u}\right)^{\zeta}+\lambda\left(A n_{c, t}^{s}\right)^{\zeta}\right]^{\frac{\alpha-\zeta}{\zeta}} \lambda A\left(A n_{c, t}^{s}\right)^{\zeta-1} \\
w_{c, t}^{u}=\alpha \theta_{c, t}\left[(1-\lambda)\left(n_{c, t}^{u}\right)^{\zeta}+\lambda\left(A n_{c, t}^{s}\right)^{\zeta}\right]^{\frac{\alpha-\zeta}{\zeta}}(1-\lambda)\left(n_{c, t}^{u}\right)^{\zeta-1} .
\end{gathered}
$$

To understand the impact of bankruptcy shocks, we take the logarithm and 
totally differentiate the above expression,

$$
\begin{gathered}
\Delta w_{c, t}^{s}=\Delta \theta_{c, t}+((\zeta-1)+(\alpha-\zeta) \pi) \Delta n_{c, t}^{s}+(\alpha-\zeta)(1-\pi) \Delta n_{c, t}^{u}, \\
\Delta w_{c, t}^{u}=\Delta \theta_{c, t}+((\zeta-1)+(\alpha-\zeta)(1-\pi)) \Delta n_{c, t}^{u}+(\alpha-\zeta)(\pi) \Delta n_{c, t}^{s}
\end{gathered}
$$

where $\Delta$ denotes percent change over time and $\pi \equiv \frac{\lambda\left(A n_{s}\right)^{\zeta}}{(1-\lambda) n_{u}^{\zeta}+\lambda\left(A n_{s}\right)^{\zeta}}$. These expressions describe the dynamics of the equilibrium response of wages to exogenous demand shocks, $\Delta \theta$, in terms of the endogenous response in employment levels, $\Delta n_{c, t}^{s}$ and $\Delta n_{c, t}^{u}$.

\subsection{Labor Supply}

The households of county $c$ work in the legal sector and differ in their labor productivity type $(j)$ : skilled $(j=s)$ and unskilled $(j=u)$. In each period $t$, households of type $j$ choose consumption $c_{j, t} \in \mathbb{R}_{+}$and labor hours $n_{j, t} \in \mathbb{R}_{+}$ in order to maximize Greenwood-Hercowitz-Huffman preferences

$$
\max _{\left\{c_{c, t}^{j}, n_{c, t}^{j}\right\}_{t=0}^{\infty}} \sum_{t=0}^{\infty} \beta^{t} \frac{1}{1-\sigma}\left(c_{c, t}^{j}-\frac{\left(n_{c, t}^{j}\right)^{1+\rho_{j}}}{1+\rho_{j}}\right)^{1-\sigma} \quad \text { s.t. } c_{c, t}^{j} \leq w_{c, t}^{j} n_{c, t}^{j},
$$

where $\rho_{j}>0$ is type $j$ 's inverse Frisch elasticity of labor supply, and $\sigma>0$ decides the agents elasticity of intertemporal substitution $\left(E I S=\frac{1}{1-\sigma}\right)$. For each hour of work supplied workers of type $j$ receive an hourly wage $w_{j, t}$. Wage compensation is their only source of income.

By totally differentiating the logarithm of the first order conditions, we obtain:

$$
\Delta n_{c, t}^{s}=\frac{1}{\rho_{s}} \Delta w_{c, t}^{s}
$$

$$
\Delta n_{c, t}^{u}=\frac{1}{\rho_{u}} \Delta w_{c, t}^{u}
$$

Equilibrium Definition An equilibrium is an allocation of consumption and labor across skilled and unskilled households, quantity of legal services, as well as wages for skilled and unskilled workers and price of legal services such that: (i) households choose consumption and labor supply to solve (5); (ii) the repre- 
sentative firm hires workers to maximize its profits; (iii) labor and legal service output markets clear.

\section{Structural Estimation and Welfare Analysis}

This section quantifies the local welfare losses experienced by legal workers as a result of large bankruptcy reorganizations being forum shopped away from their local communities. Following Notowidigdo (2020), we estimate the structural parameters of our model using a non-linear simultaneous equations GMM estimator. Then, we use the estimated model to determine the potential welfare gains associated with moving from the status-quo regime where firms forum shop to a counterfactual regime without forum shopping.

\subsection{GMM Estimation}

Our model is fully characterized by the wage and employment dynamics described in (3), (4), (6), and (7). We denote the error terms for these equations as $\Delta \epsilon_{c, t}^{j}$, and rearrange to obtain the following:

$$
\begin{gathered}
\Delta \epsilon_{c, t}^{w S}=\Delta w_{c, t}^{s}-\left[\Delta \theta_{c, t}+((\zeta-1)+(\alpha-\zeta)(\pi)) \Delta n_{c, t}^{s}+(\alpha-\zeta)(1-\pi) \Delta n_{c, t}^{u}\right] \\
\Delta \epsilon_{c, t}^{w U}=\Delta w_{c, t}^{u}-\left[\Delta \theta_{c, t}+((\zeta-1)+(\alpha-\zeta)(1-\pi)) \Delta n_{c, t}^{u}+(\alpha-\zeta)(\pi) \Delta n_{c, t}^{s}\right] \\
\Delta \epsilon_{c, t}^{n S}=\Delta n_{c, t}^{s}-\frac{1}{\rho_{s}} \Delta w_{c, t}^{s} \\
\Delta \epsilon_{c, t}^{n U}=\Delta n_{c, t}^{u}-\frac{1}{\rho_{u}} \Delta w_{c, t}^{u}
\end{gathered}
$$

The endogenous variables $\Delta w_{c, t}^{s}, \Delta w_{c, t}^{u}, \Delta n_{c, t}^{s}, \Delta n_{c, t}^{u}$ depend jointly on each other through this system of simultaneous equations. This creates a potential correlation across the error terms and can result in simultaneity bias when estimating the model parameters. However, bankruptcy shocks create exogenous variation in $\theta_{c, t}$ which implies $\Delta \theta_{c, t}$ is uncorrelated with the error terms. We address the potential simultaneity bias by jointly estimating the model parameters with a GMM procedure using equations (8), (9), (10), (11) and instruments derived from the source of exogenous variation in $\Delta \theta$. 
Our model has seven parameters that discipline the labor demand $(\zeta, A, \alpha, \pi, \lambda)$ and labor supply $\left(\rho_{s}, \rho_{u}\right)$. We calibrate four and estimate the rest using BLS data. $^{27}$ The production parameters $A, \zeta, \pi$, and $\lambda$ are calibrated as in Notowidigdo (2020). Let $\lambda=\frac{(1-\mu)^{\zeta-1}}{\left(A_{s} \mu\right)^{\zeta-1}+(1-\mu)^{\zeta-1}}$ and let $\mu=0.42$ denote the average share of skilled workers in the legal labor market. ${ }^{28}$ Then, $A=2.40$ equals the wage premium, computed as the ratio of the average wages of skilled and unskilled workers. ${ }^{29}$ Following a large body of literature, we set the elasticity of substitution equal to the estimate from Katz and Murphy (1992) of 1.4, which implies $\zeta=0.29$. Accordingly, $\pi=0.63$. We estimate the returns to scale $\alpha$, and the Frisch elasticities of substitution $1 / \rho_{s}$ and $1 / \rho_{u}$ using GMM.

We use Chapter 11 bankruptcy shocks to construct the exogenous demand shocks $\Delta \theta_{c, t}$. Let the demand for legal services for county $c$ in period $t$ be

$$
\theta_{c, t}=\bar{L}_{c}+\Phi \cdot B R_{c, t}
$$

where $B R_{c, t}$ denotes bankruptcy cases filed locally, $\bar{L}_{c}$ denotes the county's 'steady state' level of demand for legal services and $\Phi$ is the per-bankruptcy expected increase in legal expenses. By taking the logarithm and differentiating, we obtain

$$
\Delta \theta_{c, t}=\frac{\Phi \cdot\left(B R_{c, t}-B R_{c, t-1}\right)}{\bar{L}_{c}+B R_{c, t}} .
$$

We calculate $\Phi$ as the average annual legal fees for a Chapter 11 bankruptcy using Lopucki BRD. We compute $\bar{L}_{c}$ by multiplying county level GDP data for

\footnotetext{
${ }^{27}$ We use BLS data instead of CBP data for two reasons: $(i)$ it has additional granularity to help distinguish skilled and unskilled legal workers, (ii) it includes data on wages. This comes at the cost of lower geographical coverage. In Section 4.3.3 we show that our results on the impact of bankruptcies on legal employment are similar to the ones we obtain using CBP data.

${ }^{28}$ We estimate skilled employment using NAICS 54111 'Offices of Lawyers' and dividing by 2.3 using the estimate that there are 1.3 non-lawyers for every lawyer as suggested by Freedman (2005). We estimate unskilled employment using NAICS 54119 plus the portion of unskilled removed from NAICS 54111. Data is from 1990 through 2001, averaged across time. Source: BLS.

${ }^{29}$ We use the earliest available detailed occupational wage data, which is from 2000. Average wage for unskilled uses data for paralegals, legal assistants, court reporters, and law clerks. Skilled uses data for lawyers. Source: BLS.
} 
all professional and legal services (NAICS 54) ${ }^{30}$ for the average proportion of employment in that sector attributed to only the legal industry (NAICS 5411).

In our estimation, we use instrumental variables based on the two sources of exogenous variation in $\Delta \theta_{c, t}$ : the contemporaneous non-forum shopped bankruptcies $\left(B R_{c, t}\right)$ and the non-forum shopped bankruptcy in the previous period $\left(B R_{c, t-1}\right)$. To achieve identification, we also include non-linear functions of these variables. Our preferred specification (Table 7) uses combinations of $\left.\left\{B R_{c, t},\left(B R_{c, t-1}\right),\left(B R_{c, t-1}\right)^{2},\left(B R_{c, t-1}\right)^{3}, B R_{c, t-1}\right)^{4}\right\}$ and a constant as instrumental variables resulting in 14 moment conditions. We select our preferred specification using the usual $\chi^{2}$ over-identification test. Table 20 in Appendix G shows our results are supported by a variety of other choices of instruments as well.

We use BLS data to measure employment levels and wages for skilled and unskilled labor in the legal sector. As before, we omit New York and Delaware from our estimation sample. However, due to limited data availability, we expand our sample through the year 2001. Limiting the sample to only the Court Competition Era (1991-1996) yields very similar estimates albeit with lower significance due to the limited number of observations (Table 20). More information on data and sensitivity to sample selection can be found in Appendix G.

\footnotetext{
${ }^{30}$ We collect county level real GDP for NAICS 54, Professional and Business services during 2003. We use 2003 because it is a representative year not impacted by bankruptcy shocks in our sample and data was not available prior to 2000. Source: BEA.
} 
Table 7: GMM Estimates of model parameters.

\begin{tabular}{ccccc}
\hline & $1 / \rho_{s}$ & $1 / \rho_{u}$ & $\alpha$ & Observations \\
\hline Estimates & $0.0853^{* * *}$ & $0.264^{* *}$ & $1.293^{* * *}$ & 2370 \\
& $(0.0307)$ & $(0.120)$ & $(0.150)$ & \\
\hline
\end{tabular}

Standard errors clustered at county level in parentheses

${ }^{*} p<0.1,{ }^{* *} p<0.05,{ }^{* * *} p<0.01$

Note: Instruments for $\Delta \epsilon_{c, t}^{w S}$ and $\Delta \epsilon_{c, t}^{w U}:\left\{\left(B R_{c, t-1}\right),\left(B R_{c, t-1}\right)^{2},\left(B R_{c, t-1}\right)^{3},\left(B R_{c, t-1}\right)^{4}\right\}$. Instruments for $\Delta \epsilon_{c, t}^{n S}$ and $\Delta \epsilon_{c, t}^{n U}:\left\{B R_{c, t},\left(B R_{c, t-1}\right)\right\}$, constant. Wages and unemployment are detrended prior to estimation using county-year population, log of county-year employment in all non-legal sectors with fixed effects for county and district-year, where district is one of $90 \mathrm{ju}-$ dicial districts. Sample: all U.S. counties with non-zero legal employment. Period: 1991-2001. Sources: Lopucki BRD, Compustat, CBP, U.S. Census Bureau, BEA, SEC EDGAR, BLS.

Table 7 presents the results of our GMM estimation. As expected, we estimate the Frisch elasticity for the extensive margin to be lower for skilled labor $\left(1 / \rho_{s}\right)$ than it is for unskilled labor $\left(1 / \rho_{u}\right)$. These estimates are well within the 0 to 1 range found by much of the micro literature (Whalen and Reichling 2017), and are quite similar to estimates for the extensive margin that range from 0.01 to 0.7 (e.g. Bianchi, Gudmundsson, and Zoega 2001; K. M. Brown 2013). ${ }^{31}$ The estimated returns to scale parameter $\alpha$ is greater than one implying increasing returns to scale. However, the two-sided $95 \%$ confidence interval has a lower bound of 0.999 so we fail to reject the possibility of constant returns to scale. The over-identification test for this model does not reject the null hypothesis that the empirical moment conditions' deviations from 0 are due to chance $(p$ $=0.321$. Finally, Figure 7 in Appendix B demonstrates that our calibrated model predicts reasonably well the observed outcomes.

\subsection{Welfare Analysis}

With our fully calibrated model, we perform counterfactual welfare analysis to estimate the losses to workers caused by forum shopping. To do so, we measure the increase in consumption that would have made skilled and unskilled

\footnotetext{
${ }^{31}$ For the Frisch Elasticity of the extensive margin Bianchi, Gudmundsson, and Zoega (2001) estimates 0.4 for the whole labor force, ranging from 0.1 for women and 0.6 for men; K. M. Brown (2013) estimates range from 0.01 to 0.17 using workers near retirement age.
} 
households indifferent to a regime where all forum shopped bankruptcies were instead filed locally. For a household of a given labor type, the consumption equivalent variation implied by our model is defined as $\epsilon$ from the expression

$$
\sum_{t=0}^{T} \beta^{t} \frac{1}{1-\sigma}\left(c_{c, t}^{j}(1+\epsilon)-\frac{\left(n_{c, t}^{j}\right)^{1+\rho_{j}}}{1+\rho_{j}}\right)^{1-\sigma}=\sum_{t=0}^{T} \beta^{t} \frac{1}{1-\sigma}\left(\tilde{c}_{c, t}^{j}-\frac{\left(\tilde{n}_{c, t}^{j}\right)^{1+\rho_{j}}}{1+\rho_{j}}\right)^{1-\sigma}
$$

where $\tilde{c}_{c, t}^{j}$ and $\tilde{n}_{c, t}^{j}$ denote the predicted levels of consumption and labor under the counterfactual regime with no forum shopping.

Table 8: Consumption Equivalent Variation

\begin{tabular}{lcccc}
\hline \multicolumn{2}{c}{$(\sigma=2}$, & EIS $=0.5)$ \\
Skilled & Unskilled & & & \multicolumn{2}{c}{$(\sigma=0.5}$, & EIS $=2)$ \\
\cline { 5 - 6 } \cline { 5 - 6 } & & & Skilled & Unskilled \\
\hline $0.74 \%$ & $0.77 \%$ & & $0.79 \%$ & $0.82 \%$ \\
\hline
\end{tabular}

Table 8 presents our findings for the consumption equivalent variation of both worker types averaged across all counties that experienced non-forumshopped bankruptcy during the sample period. In line with the literature we present our results for a $\sigma$ of 0.5 and 2 (e.g. Havránek 2015; Karp, Peri, and Rezai (2021)). In either case, we find that both types of households would need a nearly one percent increase in their consumption level per year in order to achieve the same level of utility they otherwise would have without forum shopping. We also find that forum shopping has a larger effect on unskilled workers, who make up the majority of the labor force.

To the best of our knowledge, this is the first attempt to construct a welfare measure of the impact of forum shopping. These estimates from our parsimonious model show that moving to a regime without forum shopping can have economically significant welfare gains for workers in the legal service industry.

\section{Conclusion}

Fluctuations in the financial health of major employers play a critical role in the well-being of local labor markets. Much to the detriment of these local economies, when a large corporation files for bankruptcy employment falls 
(Bernstein et al. 2019). However, the adverse effects of bankruptcy shocks on overall local employment hides the differential impact across sectors in the local production network (Carvalho 2014). The legal sector in the bankrupt firms' local area may indeed benefit from the increased demand for legal services, a substantial transfer overlooked by the previous literature.

In this paper, we study empirically and theoretically the effect of Chapter 11 bankruptcy shocks on local legal labor markets. After constructing a novel database of Chapter 11 bankruptcy reorganizations, we find that each Chapter 11 bankruptcy reorganization of a publicly traded firm is associated with a $1 \%$ increase in county legal employment for each year of a bankruptcy. Back-of-theenvelope calculations estimate that forum shopping exported away $24 \%$ of the total potential employment gains from local communities with distressed firms.

We develop a parsimonious model of the legal service sector to structurally estimate the local welfare losses of legal sector workers in counties that experience bankruptcy shocks. Using our calibrated model, we estimate the consumption equivalent variation implied by moving from a world with forum shopping to a world without it. We find the local welfare losses to be roughly $1 \%$ for workers in the legal sector.

We focus our analysis on the Court Competition Era, a period from 1991 to 1996 that witnessed a boom in forum shopping. From a methodological point of view, we propose a novel identification approach that uses forum shopping as institutional placebo to create variation in the location of the filing court that are exogenous to local economic conditions. It is worth mentioning that forum shopping is not exclusive to bankruptcy reorganization procedures. For instance, patent laws allow for the possibility of forum shopping patent litigation cases. While the institutional details may be different, our identification approach may prove useful in that context, or other similar contexts, as well.

Our analysis uncovers economically significant costs to local communities from forum shopping. These costs have not been accounted for in either the recent policy debate around the Bankruptcy Venue Reform Act bill of 2021, or the ongoing debate in the legal literature over the efficiency of forum shopping. While these estimates may only be a preliminary look into the potentially large 
costs of forum shopping today, our analysis suggests that a deeper look at the production network of large corporate bankruptcies is necessary to fully understand the costs to local communities in a modern setting.

\section{References}

Acemoglu, Daron. 2002. "Technical Change, Inequality, and the Labor Market." Journal of Economic Literature, 99.

Acemoglu, Daron, and David Autor. 2011. "Skills, Tasks and Technologies: Implications for Employment and Earnings." In Handbook of Labor Economics. Edited by Orley C. Ashenfelter and David Card. Amsterdam: North Holland.

Armour, John, Audrey Wen-hsin Hsu, and Adrian Walters. 2012. "The Costs and Benefits of Secured Creditor Control in Bankruptcy: Evidence from the UK." Publisher: De Gruyter, Review of Law \&3 Economics 8, no. 1 (May): 101-135.

Bai, Yan, Jose-Victor Rıos-Rull, and Kjetil Storesletten. 2012. "Demand Shocks as Productivity Shocks." Under revision for Journal of Political Economy, 50.

Bennett, Benjamin, Todd T. Milbourn, and Zexi Wang. 2018. "Corporate Investment Under the Cloud of Litigation." SSRN Electronic Journal.

Bernstein, Shai, Emanuele Colonnelli, Xavier Giroud, and Benjamin Iverson. 2019. "Bankruptcy spillovers." Journal of Financial Economics, JFE Special Issue on Labor and Finance, 133, no. 3 (September 1, 2019): 608-633.

Bianchi, Marco, Bjorn R. Gudmundsson, and Gylfi Zoega. 2001. "Iceland's Natural Experiment in Supply-Side Economics." American Economic Review 91, no. 5 (December): 1564-1579.

Bowlus, Audra, Eda Bozkurt, Lance Lochner, and Chris Robinson. 2017. Wages and Employment: The Canonical Model Revisited. w24069. Cambridge, MA: NBER, November.

Brown, Kristine M. 2013. "The link between pensions and retirement timing: Lessons from California teachers." Journal of Public Economics 98 (February): 1-14.

Brown, Nick. 2013. "Kodak bankruptcy advisers likely to see $\$ 240$ million payday." Reuters (November 14, 2013).

"Occupational Employment and Wages, 2000." 2002. Bureau of Labor Statistics (April): 146.

Callaway, Brantly, and Pedro H. C. Sant'Anna. 2021. "Difference-in-Differences with multiple time periods." Journal of Econometrics 225 (December): 200-230.

Carvalho, Vasco M. 2014. "From Micro to Macro via Production Networks." Journal of Economic Perspectives 28, no. 4 (November): 23-48.

Chava, Sudheer, Baridhi Malakar, and Manpreet Singh. 2021. "Communities as Stakeholders: Impact of Corporate Bankruptcies on Local Governments." Unpublished working paper.

Cole, Marcus. 2003. "'Delaware is Not a State": Are We Witnessing Jurisdictional Competition in Bankruptcy?" Vanderbilt Law Review 55.

Corbae, Dean, and Pablo D'Erasmo. 2021. "Reorganization or Liquidation: Bankruptcy Choice and Firm Dynamics." The Review of Economic Studies 88, no. 5 (October): 2239-2274.

Criscuolo, Chiara, Ralf Martin, Henry G. Overman, and John Van Reenen. 2019. "Some Causal Effects of an Industrial Policy." American Economic Review 109 (1).

Cunningham, Scott, and Manisha Shah. 2014. Decriminalizing Indoor Prostitution: Implications for Sexual Violence and Public Health. w20281. NBER, July 10, 2014. 
Eckert, Fabian, Teresa C. Fort, Peter K. Schott, and Natalie Yang. 2019. Imputing Missing Values in the US Census Bureau's County Business Patterns. Technical report. NBER.

Eisenberg, Theodore, and Lynn LoPucki. 1999. "Shopping for Judges: An Empirical Analysis of Venue Choice in Large Chapter 11 Reorganizations." Cornell Law Review 84:967.

Ellias, Jared A. 2019. "Bankruptcy Law: Explaining Bankruptcy Forum Shopping." 3:11.

Franks, Julian R., Kjell G. Nyborg, and Walter N. Torous. 1996. "A Comparison of US, UK, and German Insolvency Codes." Financial Management 25 (3): 86-101.

Freedman, Ellen. 2005. "How Many Non-Lawyers Does it Take to Run a Law Firm?"

GDP by County, Metro, and Other Areas - U.S. Bureau of Economic Analysis (BEA). Accessed September 22, 2021.

Gennaioli, Nicola, and Stefano Rossi. 2010. "Judicial Discretion in Corporate Bankruptcy." Publisher: Society for Financial Studies, Review of Financial Studies 23 (11): 4078-4114.

Hamilton, James. 2020. Dates of U.S. recessions as inferred by GDP-based recession indicator.

Hausman, Joshua K. 2016. "Fiscal Policy and Economic Recovery: The Case of the 1936 Veterans' Bonus." American Economic Review 106, no. 4 (April 1, 2016): 1100-1143.

Havránek, Tomáš. 2015. "Measuring Intertemporal Substitution: The Importance of Method Choices and Selective Reporting." Journal of the European Economic Association 13, no. 6 (December 1, 2015): 1180-1204.

Karp, Larry S., Alessandro Peri, and Armon Rezai. 2021. Selfish incentives for climate policy: Empower the young! SSRN Scholarly Paper ID 3933987. Rochester, NY: Social Science Research Network, September.

Katz, Lawrence F., and Kevin M. Murphy. 1992. "Changes in Relative Wages, 1963-1987: Supply and Demand Factors." Publisher: Oxford University Press, The Quarterly Journal of Economics 107 (1): 35-78.

Leary, Marie, Bob Niemic, and Melissa Deckman. 1999. "Standards Governing Attorney Conduct in the Bankruptcy Courts" [in en]. Final Report, 102.

Lee, Ruth Sarah. 2011. Delaware's Relevance in Chapter 22: Who is 'Courting Failure' Now? SSRN Scholarly Paper ID 1938814. Rochester, NY: Social Science Research Network, May.

LoPucki, Lynn, and Sara Kalin. 2000. "The Failure of Public Company Bankruptcies in Delaware and New York: Empirical Evidence of a 'Race to the Bottom'." Vanderbilt Law Review 54.

LoPucki, Lynn M. 2005. Courting Failure: How Competition for Big Cases Is Corrupting the Bankruptcy Courts. University of Michigan Press. IsBN: 978-0-472-11486-3.

—. 2006. "Where Do You Get Off - A Reply to Courting Failure's Critics Courting Failure." Buffalo Law Review 54.

LoPucki, Lynn M., and William C. Whitford. 1991. "Venue Choice and Forum Shopping in the Bankruptcy Reorganization of Large, Publicly Held Companies." Wisconsin Law Review 1991 (1): 11-64.

M. M. Buehlmaier, Matthias. 2014. "Debt, equity, and information." Journal of Mathematical Economics 50 (January): 54-62.

Mahoney, Neale. 2015. "Bankruptcy as Implicit Health Insurance." Publisher: American Economic Association, The American Economic Review 105, no. 2 (February): 710-746.

Notowidigdo, Matthew J. 2020. "The Incidence of Local Labor Demand Shocks." Publisher: The University of Chicago Press, Journal of Labor Economics 38, no. 3 (July): 687-725.

Okray, John. 2016. "Attorney Admission Practices in the U.S. Federal Courts" [in en]. The Federal Lawyer (September): 6. 
Rajan, Raghuram, and Rodney Ramcharan. 2015. "The Anatomy of a Credit Crisis: The Boom and Bust in Farm Land Prices in the United States in the 1920s." American Economic Review 105, no. 4 (April 1, 2015): 1439-1477.

Rogerson, Richard, and Johanna Wallenius. 2009. "Micro and macro elasticities in a life cycle model with taxes." Journal of Economic Theory, Dynamic General Equilibrium, 144, no. 6 (November): 2277-2292.

"SEC.gov - EDGAR - Search and Access." n.d.

Skeel, David A. 1998. "Bankruptcy Judges and Bankruptcy Venue: Some Thoughts on Delaware." Faculty Scholarship at Penn Law 719.

Sun, Liyang, and Sarah Abraham. 2020. "Estimating Dynamic Treatment Effects in Event Studies with Heterogeneous Treatment Effects" (September 22, 2020): 53.

Thomas, Randall, and Robert K. Rasmussen. 2001. "Whither the Race? A Comment on the Effects of the Delawarization of Corporate Reorganizations." Vanderbilt Law Review 54.

U.S. Bureau of Economic Analysis. 1997. "Gross Domestic Product: Legal Services (NAICS 5411) and Agriculture, Forestry, Fishing and Hunting (NAICS 11) in the United States," January 1, 1997.

"U.S. Bureau of Labor Statistics Databases." n.d.

"US Census Bureau." Census.gov. n.d. Section: Intercensal Datasets.

Whalen, Charles, and Felix Reichling. 2017. "Estimates of the Frisch Elasticity of Labor Supply: A Review." Eastern Economic Journal 43, no. 1 (January): 37-42.

Wise, Ric. 2020. QCEW Data Files : U.S. Bureau of Labor Statistics, August 20, 2020.

Zywicki, Todd J. 2006. "Is Forum-Shopping Corrupting America's Bankruptcy Courts? Review of Lynn M. Lopucki, 'Courting Failure: How Competition for Big Cases is Corrupting the Bankruptcy Courts'." Georgetown Law Journal 94. 


\section{Appendices}

\section{A Summary Stats}

Table 9: Descriptive Statistics for County Level Economic Measures.

\begin{tabular}{lcccc}
\hline & \multicolumn{2}{c}{ Full Sample } & \multicolumn{2}{c}{ County-Year with BR } \\
& Mean & Std. Dev. & Mean & Std. Dev. \\
\hline Legal Emp & 305 & 1661 & 5029 & 7761 \\
County Pop. & 88769 & 281261 & 915621 & 1240253 \\
Employment Non-Legal & 32785 & 118582 & 406210 & 510300 \\
\hline Observations & 16058 & & 451 & \\
\hline
\end{tabular}

Note: County data descriptive statistics for employment in the legal sector, county population, employment in all sectors besides legal services. Sources: Lopucki BRD, Compustat, CBP, U.S. Census Bureau, BEA, SEC EDGAR.

Full Sample: All counties with non-zero legal employment during the period 1991-1996, not including counties from New York and Delaware.

County-Year with BR: All counties where at least one bankruptcy took place during the period 1991-1996, not including counties from New York and Delaware.

\section{B Figures}

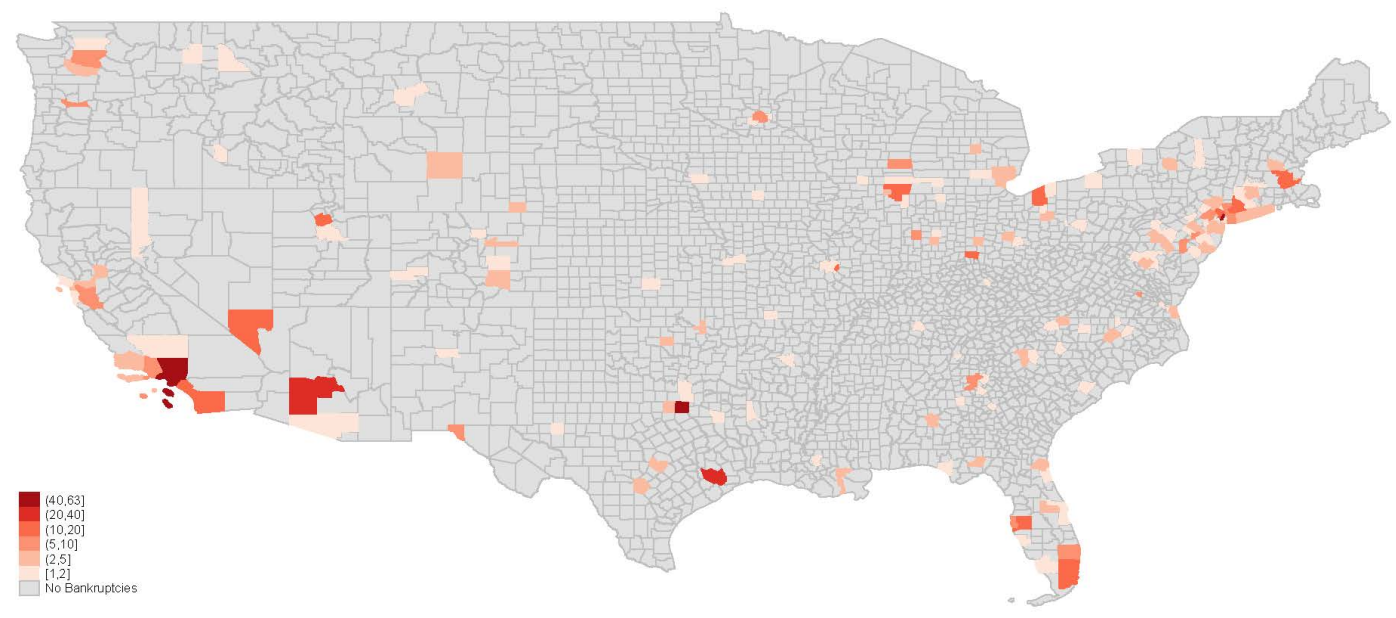

Figure 3: Number of Ch11 Bankruptcies in each county from 1991 to 1996. 


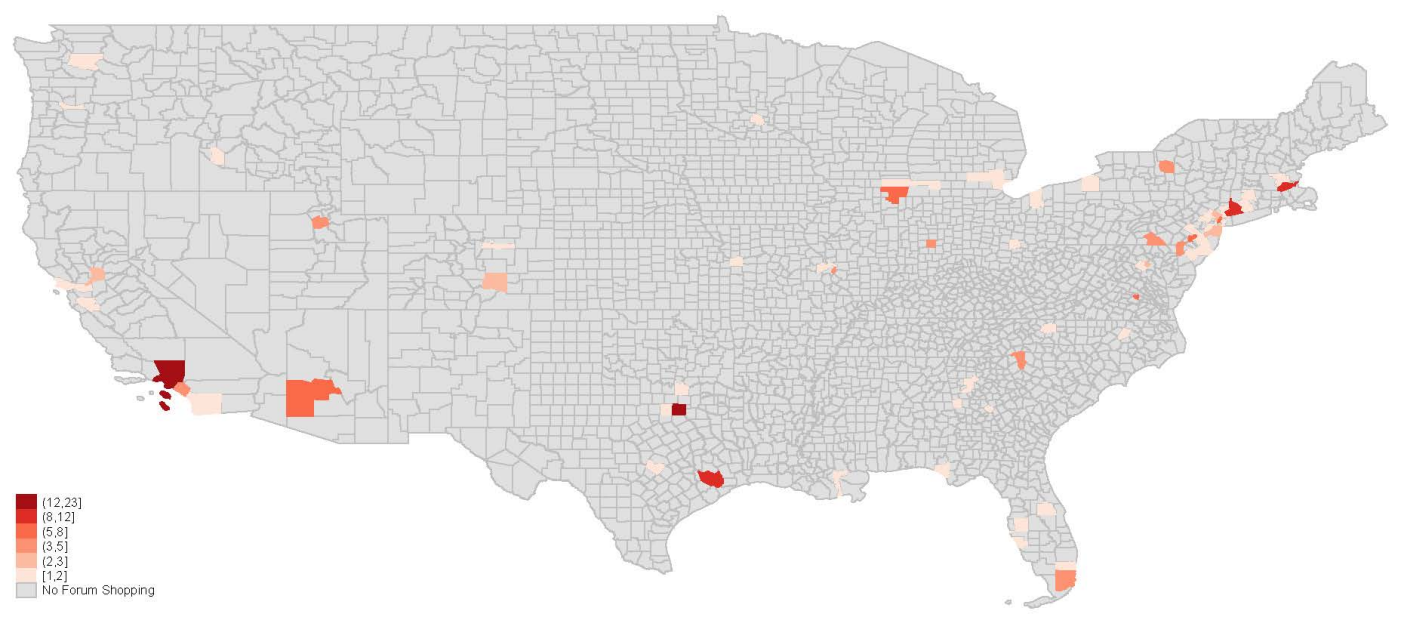

Figure 4: Number of Forum Shopped Ch11 Bankruptcies in each county from 1991 to 1996.
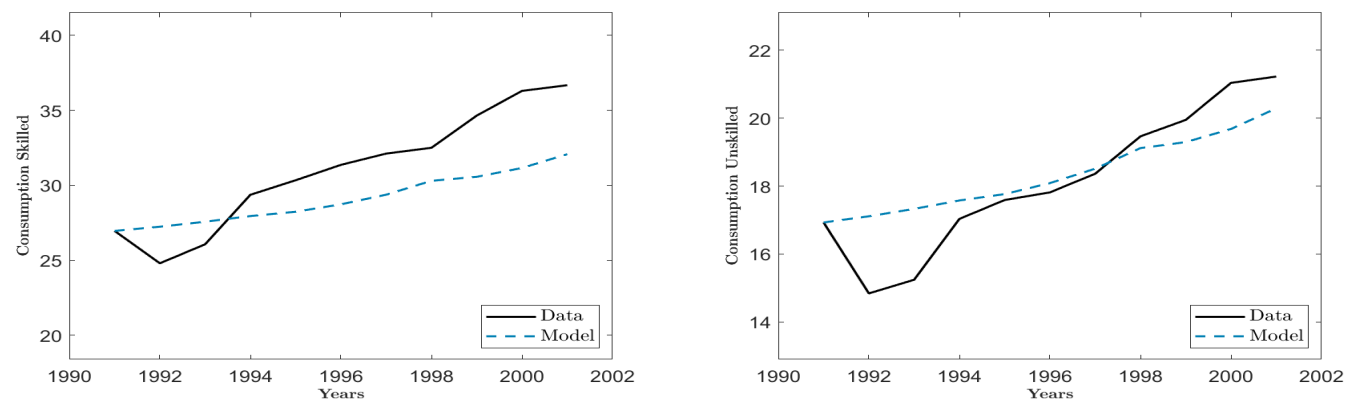

Figure 7: Calibrated Model Predicted Values vs. Observed Values - Comparison of predicted consumption levels to the observed levels in the data for counties who experience at least one non-forum shopped bankruptcy shock during the estimation period.

\section{Placebo Tests}

Here we present an additional placebo exercise to accompany Section 4.1.1. Table 10 presents placebo regression using an binary indicator for bankruptcy as opposed to the count measure used in Table 5. 
Table 10: Employment Level Regressions with lags for dummy indicator of bankruptcy shock.

\begin{tabular}{|c|c|c|c|c|}
\hline & (1) & $(2)$ & $(3)$ & (4) \\
\hline L1.Bankruptcy & $\begin{array}{c}0.00368 \\
(0.00694)\end{array}$ & & & $\begin{array}{c}0.00413 \\
(0.00679)\end{array}$ \\
\hline L2.Bankruptcy & & $\begin{array}{c}-0.00160 \\
(0.00606)\end{array}$ & & $\begin{array}{l}-0.00205 \\
(0.00581)\end{array}$ \\
\hline L3.Bankruptcy & & & $\begin{array}{c}0.00109 \\
(0.00810)\end{array}$ & $\begin{array}{c}0.00181 \\
(0.00815)\end{array}$ \\
\hline $\ln$ (County Population) & $\begin{array}{c}0.715^{* * *} \\
(0.144)\end{array}$ & $\begin{array}{c}0.716^{* * *} \\
(0.144)\end{array}$ & $\begin{array}{c}0.715^{* * *} \\
(0.144)\end{array}$ & $\begin{array}{c}0.715^{* * *} \\
(0.144)\end{array}$ \\
\hline $\ln ($ Emp Non-Legal) & $\begin{array}{l}0.170^{* * *} \\
(0.0489)\end{array}$ & $\begin{array}{l}0.170^{* * *} \\
(0.0489)\end{array}$ & $\begin{array}{l}0.171^{* * *} \\
(0.0490)\end{array}$ & $\begin{array}{l}0.171^{* * *} \\
(0.0490)\end{array}$ \\
\hline $\begin{array}{l}\text { County FE } \\
\text { District-Year FE } \\
\text { R-Squared } \\
\text { Observations }\end{array}$ & $\begin{array}{c}\text { Yes } \\
\text { Yes } \\
0.984 \\
15931\end{array}$ & $\begin{array}{c}\text { Yes } \\
\text { Yes } \\
0.984 \\
15931\end{array}$ & $\begin{array}{c}\text { Yes } \\
\text { Yes } \\
0.984 \\
15930\end{array}$ & $\begin{array}{c}\text { Yes } \\
\text { Yes } \\
0.984 \\
15930\end{array}$ \\
\hline \multicolumn{5}{|c|}{$\begin{array}{l}\text { Standard errors clustered at county level in parentheses } \\
{ }^{*} p<0.1,{ }^{* *} p<0.05,{ }^{* * *} p<0.01\end{array}$} \\
\hline \multicolumn{5}{|c|}{$\begin{array}{l}\text { Note: OLS regression estimates of log Legal Employment on: (i) Treatment: bankruptcy dummy } \\
\text { lagged one, two, or three years; (ii) Fixed Effects: county and district-year, where district is one of } \\
90 \text { judicial districts; (iii) Controls: log of county-year population, log of county-year employment in } \\
\text { all non-legal sectors. Sample: All U.S. counties with non-zero legal employment, omitting Delaware } \\
\text { and New York. Period: 1991-1996. Sources: Lopucki BRD, Compustat, CBP, U.S. Census Bureau, } \\
\text { BEA, SEC EDGAR. }\end{array}$} \\
\hline
\end{tabular}

\section{Fixed Effects}

This section reports the results for our main forum shopping regressions across a variety of different fixed effect specifications. Table 11 reports our forum shopping regressions- as in specification (2)- for each of the fixed effects used in Table 4: county, county and year, county and region-year, county and divisionyear, county and state-year, county and district-year. In each case, they confirm our results and show that the combined effect of a forum shopped bankruptcy is not statistically different from 0. Recall that Column (2) of Table 6 reports these results for county and district-year fixed effects, which is our preferred specification and the most stringent fixed effects. Note that for completeness 
the estimates for the controls are also included here, although they are omitted in the main body of the paper.

Table 11: Employment Level Regressions

\begin{tabular}{lcccccc}
\hline & $(1)$ & $(2)$ & $(3)$ & $(4)$ & $(5)$ & $(6)$ \\
\hline Bankruptcies & $0.00948^{* * *}$ & $0.0101^{* * *}$ & $0.0100^{* * *}$ & $0.00862^{* *}$ & $0.00878^{* *}$ & $0.0100^{* * *}$ \\
& $(0.00349)$ & $(0.00355)$ & $(0.00356)$ & $(0.00348)$ & $(0.00385)$ & $(0.00373)$ \\
Forum Shopping & -0.00741 & $-0.00873^{*}$ & -0.00689 & -0.00772 & -0.00759 & $-0.0111^{*}$ \\
& $(0.00518)$ & $(0.00518)$ & $(0.00522)$ & $(0.00527)$ & $(0.00623)$ & $(0.00637)$ \\
$\ln$ (County Population) $)$ & $0.797^{* * *}$ & $0.750^{* * *}$ & $0.694^{* * *}$ & $0.651^{* * *}$ & $0.726^{* * *}$ & $0.715^{* * *}$ \\
& $(0.115)$ & $(0.125)$ & $(0.134)$ & $(0.134)$ & $(0.137)$ & $(0.144)$ \\
$\ln ($ Emp Non-Legal) & $0.182^{* * *}$ & $0.166^{* * *}$ & $0.170^{* * *}$ & $0.174^{* * *}$ & $0.167^{* * *}$ & $0.170^{* * *}$ \\
& $(0.0418)$ & $(0.0468)$ & $(0.0474)$ & $(0.0479)$ & $(0.0481)$ & $(0.0489)$ \\
\hline & & & & & & \\
Fixed Effects & & & & & & \\
County & Yes & Yes & Yes & Yes & Yes & Yes \\
Year & No & Yes & No & No & No & No \\
Region-Year & No & No & Yes & No & No & No \\
Division-Year & No & No & No & Yes & No & No \\
State-Year & No & No & No & No & Yes & No \\
District-Year & No & No & No & No & No & Yes \\
\hline & & & & & & \\
R-Squared & 0.984 & 0.984 & 0.984 & 0.984 & 0.984 & 0.984 \\
Observations & 15963 & 15963 & 15963 & 15963 & 15963 & 15931 \\
\hline
\end{tabular}

Standard errors clustered at county level in parentheses

${ }^{*} p<0.1,{ }^{* *} p<0.05,{ }^{* * *} p<0.01$

Note: OLS regression estimates of log Legal Employment on: (i) Treatment: number of bankruptcies, number of forum shopped bankruptcies; (ii) Fixed Effects: county; county and year; county and region-year, where region is one of 4 Census Bureau-designated regions; county and division-year, where division is one of 9 Census Bureaudesignated divisions; county and state-year; county and district-year, where district is one of 90 judicial districts; (iii) Controls: $\log$ of county-year population, log of county-year employment in all non-legal sectors. Sample: All U.S. counties with non-zero legal employment, omitting Delaware and New York. Period: 1991-2001all U.S. counties with non-zero legal employment. Sources: Lopucki BRD, Compustat, CBP, U.S. Census Bureau, BEA, SEC EDGAR.

\section{E NYDE Forum Shopping}

In Section 4.4 we are interested in estimating the number of jobs being lost due to forum shopping to New York and Delaware from local communities affected by bankruptcies. In this section, we verify that the estimated effect of forum shopping does not change when only forum shopping to New York 
and Delaware is considered. Table 12 confirms this conjecture, as the estimated effect of bankruptcy and forum shopping is nearly identical to Table 6 .

Table 12: Employment Level Regressions with Forum Shopping Only to NY or DE

\begin{tabular}{lccc}
\hline & $(1)$ & $(2)$ & $(3)$ \\
\hline Bankruptcies & $0.00791^{* *}$ & $0.0100^{* * *}$ & \\
& $(0.00334)$ & $(0.00373)$ & \\
Non-FS Bankruptcies & & & $0.0100^{* * *}$ \\
& & & $(0.00373)$ \\
Forum Shopping to NYDE & & $-0.0126^{*}$ & -0.00252 \\
& & $(0.00659)$ & $(0.00560)$ \\
\hline County FE & Yes & Yes & Yes \\
District-Year FE & Yes & Yes & Yes \\
R-Squared & 0.984 & 0.984 & 0.984 \\
Observations & 15931 & 15931 & 15931 \\
\hline
\end{tabular}

Standard errors clustered at county level in parentheses

${ }^{*} p<0.1,{ }^{* *} p<0.05,{ }^{* * *} p<0.01$

Note: OLS regression estimates of log Legal Employment on: (i) Treatment: number of bankruptcies, number of bankruptcies forum shopped to NY or DE; (ii) Fixed Effects: county and district-year, where district is one of 90 judicial districts; (iii) Controls: log of county-year population, log of county-year employment in all non-legal sectors. Sample: All U.S. counties with non-zero legal employment, omitting Delaware and New York. Period: 1991-1996. Sources: Lopucki BRD, Compustat, CBP, U.S. Census Bureau, BEA, SEC EDGAR.

\section{F Robustness Checks}

This section reports several robustness exercises discussed in Section 4.3 aimed at addressing potential concerns regarding our empirical results. We group these robustness exercises in three broad categories: (i) sample definition, (ii) controls included, and (iii) key variable measurement. In all cases our main results are unchanged. 


\section{F.1 Sample}

In this subsection, we show that our results are robust to adjusting our sample considered in the regression analysis along several dimensions. First, Table 13 adjusts the sample by including New York and Delaware counties data in Columns (1) and (2) then by dropping 1991 from our benchmark sample period in Columns (3) and (4). Second, Table 14 limits the sample to more relevant counties by only including: (i) counties where a publicly traded firm was located at any time between 1991 and 1996, (ii) counties where at least one bankruptcy took place during our sample period (1991-1996), (iii) counties where district courts are located. Note that for the disctrict court sample (iii) we use stateyear fixed effects due to perfect colinearity for many districts that have only 1 bankruptcy court. Finally in Table 15 we extend our sample to cover the period 1991-2001, we do not include forum shoppping because this is outside of the Court Competition Era. See Section 4.3.1 for a detailed discussion.

Table 13: Employment Level Regressions

\begin{tabular}{lcccc}
\hline & \multicolumn{2}{c}{ Include NYDE } & \multicolumn{2}{c}{ Drop 1991 } \\
& $(1)$ & $(2)$ & $(3)$ & $(4)$ \\
\hline Bankruptcies & $0.00669^{* *}$ & $0.00836^{* *}$ & $0.00831^{* *}$ & $0.0111^{* *}$ \\
& $(0.00308)$ & $(0.00335)$ & $(0.00410)$ & $(0.00478)$ \\
Forum Shopping & & -0.00856 & & $-0.0118^{*}$ \\
& & $(0.00577)$ & & $(0.00702)$ \\
\hline County FE & Yes & Yes & Yes & Yes \\
District-Year FE & Yes & Yes & Yes & Yes \\
R-Squared & 0.985 & 0.985 & 0.986 & 0.986 \\
Observations & 16314 & 16314 & 13327 & 13327 \\
\hline
\end{tabular}

Standard errors clustered at county level in parentheses

${ }^{*} p<0.1,{ }^{* *} p<0.05,{ }^{* * *} p<0.01$

Note: OLS regression estimates of log Legal Employment on: (i) Treatment: number of bankruptcies, number of forum shopped bankruptcies; (ii) Fixed Effects: county and districtyear, where district is one of 90 judicial districts; (iii) Controls: log of county-year population, log of county-year employment in all non-legal sectors. Sample: Columns (1) and (2) all U.S. counties with non-zero legal employment; Columns (3) and (4) all U.S. counties with non-zero legal employment, omitting Delaware and New York. Period: Columns (1) and (2) 1991-1996; Columns (3) and (4) 1992-1996. Sources: Lopucki BRD, Compustat, CBP, U.S. Census Bureau, BEA, SEC EDGAR. 
Table 14: Employment Level Regressions

\begin{tabular}{lcccccc}
\hline & \multicolumn{2}{c}{ HQ Sample } & \multicolumn{2}{c}{ BR Sample } & \multicolumn{2}{c}{ Court Sample } \\
& $(1)$ & $(2)$ & $(3)$ & $(4)$ & $(5)$ & $(6)$ \\
\hline Bankruptcies & $0.00596^{*}$ & $0.00861^{* *}$ & $0.0113^{* *}$ & $0.0145^{* * *}$ & $0.00874^{* *}$ & $0.00832^{* *}$ \\
& $(0.00320)$ & $(0.00375)$ & $(0.00468)$ & $(0.00542)$ & $(0.00390)$ & $(0.00410)$ \\
Forum Shopping & & $-0.0127^{*}$ & & -0.0125 & & 0.00258 \\
& & $(0.00710)$ & & $(0.00825)$ & & $(0.00507)$ \\
\hline County FE & Yes & Yes & Yes & Yes & Yes & Yes \\
State-Year FE & No & No & No & No & Yes & Yes \\
District-Year FE & Yes & Yes & Yes & Yes & No & No \\
R-Squared & 0.995 & 0.995 & 0.999 & 0.999 & 0.999 & 0.999 \\
Observations & 5070 & 5070 & 354 & 354 & 1074 & 1074 \\
\hline
\end{tabular}

Standard errors clustered at county level in parentheses

${ }^{*} p<0.1,{ }^{* *} p<0.05,{ }^{* * *} p<0.01$

Note: OLS regression estimates of log Legal Employment on: (i) Treatment: number of bankruptcies, number of forum shopped bankruptcies; (ii) Fixed Effects: county and district-year, where district is one of 90 judicial districtsor county and state-year; (iii) Controls: log of county-year population, log of county-year employment in all non-legal sectors. Sample: Columns (1) and (2) subset of counties that had a publicly traded companies HQ at any point in the period 1991 through 1996, omitting Delaware and New York; Columns (3) and (4) all county-year observations that had atleast 1 bankruptcy, omitting Delaware and New York; Columns (5) and (6) subset of counties that where a bankruptcy court is located, omitting Delaware and New York. Period: 1991-1996. Sources: Lopucki BRD, Compustat, CBP, U.S. Census Bureau, BEA, SEC EDGAR. 
Table 15: Employment Level Regressions

\begin{tabular}{lcccccc}
\hline & $(1)$ & $(2)$ & $(3)$ & $(4)$ & $(5)$ & $(6)$ \\
\hline Bankruptcies & $0.0108^{* * *}$ & $0.0100^{* *}$ & $0.0116^{* *}$ & $0.00960^{* *}$ & $0.0112^{* *}$ & $0.0115^{* * *}$ \\
& $(0.00357)$ & $(0.00394)$ & $(0.00459)$ & $(0.00448)$ & $(0.00444)$ & $(0.00402)$ \\
$\ln$ (County Population) $)$ & $1.104^{* * *}$ & $0.934^{* * *}$ & $0.892^{* * *}$ & $0.858^{* * *}$ & $0.917^{* * *}$ & $0.904^{* * *}$ \\
& $(0.0731)$ & $(0.0743)$ & $(0.0859)$ & $(0.0868)$ & $(0.0797)$ & $(0.0785)$ \\
$\ln$ Emp Non-Legal) $)$ & $0.335^{* * *}$ & $0.221^{* * *}$ & $0.223^{* * *}$ & $0.230^{* * *}$ & $0.218^{* * *}$ & $0.224^{* * *}$ \\
& $(0.0387)$ & $(0.0444)$ & $(0.0471)$ & $(0.0483)$ & $(0.0458)$ & $(0.0453)$ \\
\hline \multirow{3}{*}{ Fixed Effects } & & & & & & \\
County & Yes & Yes & Yes & Yes & Yes & Yes \\
Year & No & Yes & No & No & No & No \\
Region-Year & No & No & Yes & No & No & No \\
Division-Year & No & No & No & Yes & No & No \\
State-Year & No & No & No & No & Yes & No \\
District-Year & No & No & No & No & No & Yes \\
\hline \multirow{2}{*}{ R-Squared } & & & & & \\
Observations & 0.973 & 0.974 & 0.975 & 0.975 & 0.974 & 0.974 \\
\hline Star & 29877 & 29877 & 29877 & 29822 & 29877 & 29877 \\
\hline
\end{tabular}

Standard errors clustered at county level in parentheses

${ }^{*} p<0.1,{ }^{* *} p<0.05,{ }^{* * *} p<0.01$

Note: OLS regression estimates of log Legal Employment on: (i) Treatment: number of bankruptcies; (ii) Fixed Effects: county; county and year; county and region-year, where region is one of 4 Census Bureau-designated regions; county and division-year, where division is one of 9 Census Bureau-designated divisions; county and state-year; county and district-year, where district is one of 90 judicial districts; (iii) Controls: log of countyyear population, $\log$ of county-year employment in all non-legal sectors. Sample: All U.S. counties with non-zero legal employment, omitting Delaware and New York. Period: 1991-2001. Sources: Lopucki BRD, Compustat, CBP, U.S. Census Bureau, BEA, SEC EDGAR.

\section{F.2 Controls}

In our benchmark specification, we include county level controls for the log of population and the log of the number of employees outside of the legal sector. In this subsection, Table 16 extends our set of controls by lagging the controls and by including new time-varying county variables: unemployment rate, and percent change in number of non-legal establishments. See Section 4.3.2 for a detailed discussion. 
Table 16: Employment Level Regressions

\begin{tabular}{|c|c|c|c|c|c|c|}
\hline & \multicolumn{2}{|c|}{ Lagged Controls } & \multicolumn{2}{|c|}{ Unemployment Rate } & \multicolumn{2}{|c|}{$\% \Delta$ (Non-Legal Estabs) } \\
\hline & (1) & $(2)$ & $(3)$ & $(4)$ & $(5)$ & (6) \\
\hline Bankruptcies & $\begin{array}{c}0.00803^{* *} \\
(0.00329)\end{array}$ & $\begin{array}{l}0.0101^{* * *} \\
(0.00373)\end{array}$ & $\begin{array}{l}0.00758^{* *} \\
(0.00334)\end{array}$ & $\begin{array}{c}0.00998^{* * *} \\
(0.00372)\end{array}$ & $\begin{array}{l}0.00794^{* *} \\
(0.00348)\end{array}$ & $\begin{array}{l}0.0104^{* * *} \\
(0.00384)\end{array}$ \\
\hline Forum Shopping & & $\begin{array}{c}-0.00989 \\
(0.00652)\end{array}$ & & $\begin{array}{c}-0.0114^{*} \\
(0.00642)\end{array}$ & & $\begin{array}{c}-0.0119^{*} \\
(0.00642)\end{array}$ \\
\hline $\ln$ (County Population) & & & $\begin{array}{c}0.719^{* * *} \\
(0.144)\end{array}$ & $\begin{array}{c}0.719^{* * *} \\
(0.144)\end{array}$ & $\begin{array}{c}0.716^{* * *} \\
(0.144)\end{array}$ & $\begin{array}{c}0.716^{* * *} \\
(0.144)\end{array}$ \\
\hline $\ln ($ Emp Non-Legal $)$ & & & $\begin{array}{l}0.175^{* * *} \\
(0.0496)\end{array}$ & $\begin{array}{l}0.175^{* * *} \\
(0.0496)\end{array}$ & $\begin{array}{l}0.161^{* * *} \\
(0.0481)\end{array}$ & $\begin{array}{l}0.161^{* * *} \\
(0.0481)\end{array}$ \\
\hline L. $\ln$ (County Population) & $\begin{array}{c}0.855^{* * *} \\
(0.149)\end{array}$ & $\begin{array}{c}0.855^{* * *} \\
(0.149)\end{array}$ & & & & \\
\hline L.ln(Emp Non-Legal) & $\begin{array}{l}0.126^{* * *} \\
(0.0402)\end{array}$ & $\begin{array}{l}0.126^{* * *} \\
(0.0402)\end{array}$ & & & & \\
\hline Unemployment Rate & & & $\begin{array}{c}0.00274 \\
(0.00283)\end{array}$ & $\begin{array}{c}0.00275 \\
(0.00283)\end{array}$ & & \\
\hline$\% \Delta$ (Non-Legal Establishments) & & & & & $\begin{array}{c}0.0774 \\
(0.0722)\end{array}$ & $\begin{array}{c}0.0774 \\
(0.0722)\end{array}$ \\
\hline County FE & Yes & Yes & Yes & Yes & Yes & Yes \\
\hline District-Year FE & Yes & Yes & Yes & Yes & Yes & Yes \\
\hline R-Squared & 0.984 & 0.984 & 0.984 & 0.984 & 0.984 & 0.984 \\
\hline Observations & 15931 & 15931 & 15931 & 15931 & 15925 & 15925 \\
\hline
\end{tabular}

Standard errors clustered at county level in parentheses

${ }^{*} p<0.1,{ }^{* *} p<0.05,{ }^{* * *} p<0.01$

Note: OLS regression estimates of log Legal Employment on: (i) Treatment: number of bankruptcies, number of forum shopped bankruptcies; (ii) Fixed Effects: county and district-year, where district is one of 90 judicial districts; (iii) Controls: Columns (1) and (2) log of previous years population for each county-year observation, log of previous years employment in all non-legal sectors for each county-year observation; Columns (3) and (4) log of county-year population, log of county-year employment in all non-legal sectors, and county-year unemployment rate; Columns (5) and (6) log of county-year population, log of county-year employment in all non-legal sectors, and county-year change in the log of the number of establishments in non-legal sectors from previous year. Sample: All U.S. counties with non-zero legal employment, omitting Delaware and New York. Period: 1991-1996. Sources: Lopucki BRD, Compustat, CBP, U.S. Census Bureau, BEA, SEC EDGAR, BLS

\section{F.3 Measurement}

In this subsection, we explore the robustness of our main results to alternative measurements of treatment and employment. The value weighted versions measure the total assets of all the bankrupt firms in billions of 2021 dollars. Table 17 gives alternative treatment measurement results by using binary indicators, or value weighted versions when measuring bankruptcies and forum shopping. Table 18 Columns (1) and (2) include an additional measure of the number of bankruptcies in adjacent counties to capture spillover effects; then Columns (3) and (4) use BLS data instead of CBP data to measure legal and non-legal employment for the dependent variable and controls respectively. In all cases, our 
findings are aligned with our priors. See Section 4.3.3 for a detailed discussion.

Table 17: Employment Level Regressions

\begin{tabular}{lcccc}
\hline & \multicolumn{2}{c}{ Binary } & \multicolumn{2}{c}{ Value Weighted } \\
& $(1)$ & $(2)$ & $(3)$ & $(4)$ \\
\hline Bankruptcy & 0.0141 & $0.0174^{*}$ & & \\
& $(0.00862)$ & $(0.0101)$ & & \\
Forum Shop & & -0.0121 & & \\
& & $(0.0102)$ & & \\
BR Firm's Assets (2021 dollars) & & & $0.00219^{* *}$ & $0.00281^{* *}$ \\
& & & $(0.00103)$ & $(0.00132)$ \\
FS Firm's Assets (2021 dollars) & & & & -0.00198 \\
& & & & $(0.00204)$ \\
\hline County FE & Yes & Yes & Yes & Yes \\
District-Year FE & Yes & Yes & Yes & Yes \\
R-Squared & 0.984 & 0.984 & 0.984 & 0.984 \\
Observations & 15931 & 15931 & 15931 & 15931 \\
\hline
\end{tabular}

Standard errors clustered at county level in parentheses

${ }^{*} p<0.1,{ }^{* *} p<0.05,{ }^{* * *} p<0.01$

Note: OLS regression estimates of log Legal Employment on: (i) Treatment: Columns (1) and (2) dummy variables indicating whether any bankruptcies or forum shopping occured; Columns (3) and (4) bankruptcy and forum shopping measured by the sum of assets for the firms at the time of their filing. Assets measured in billions of 2021 dollars; (ii) Fixed Effects: county and district-year, where district is one of 90 judicial districts; (iii) Controls: log of county-year population, log of county-year employment in all non-legal sectors. Sample: All U.S. counties with non-zero legal employment, omitting Delaware and New York. Period: 1991-1996. Sources: Lopucki BRD, Compustat, CBP, U.S. Census Bureau, BEA, SEC EDGAR. 
Table 18: Employment Level Regressions

\begin{tabular}{|c|c|c|c|c|}
\hline & \multicolumn{2}{|c|}{ Spillover } & \multicolumn{2}{|c|}{ BLS Data } \\
\hline & (1) & $(2)$ & (3) & $(4)$ \\
\hline Bankruptcies & $\begin{array}{l}0.00658^{*} \\
(0.00358)\end{array}$ & $\begin{array}{l}0.00889^{* *} \\
(0.00399)\end{array}$ & $\begin{array}{l}0.00569^{* *} \\
(0.00282)\end{array}$ & $\begin{array}{c}0.00856^{* * *} \\
(0.00321)\end{array}$ \\
\hline Forum Shopping & & $\begin{array}{l}-0.0109^{*} \\
(0.00633)\end{array}$ & & $\begin{array}{r}-0.0136^{* * *} \\
(0.00496)\end{array}$ \\
\hline Adjacent County Bankruptcies & $\begin{array}{l}-0.00337 \\
(0.00358)\end{array}$ & $\begin{array}{l}-0.00336 \\
(0.00358)\end{array}$ & & \\
\hline County FE & Yes & Yes & Yes & Yes \\
\hline District-Year FE & Yes & Yes & Yes & Yes \\
\hline R-Squared & 0.984 & 0.984 & 0.996 & 0.996 \\
\hline Observations & 15931 & 15931 & 10684 & 10684 \\
\hline \multicolumn{5}{|c|}{$\begin{array}{l}\text { Standard errors clustered at county level in parentheses } \\
{ }^{*} p<0.1,{ }^{* *} p<0.05,{ }^{* * *} p<0.01\end{array}$} \\
\hline \multicolumn{5}{|c|}{$\begin{array}{l}\text { Note: OLS regression estimates of log Legal Employment on: (i) Treatment: number of bankruptcies, } \\
\text { number of forum shopped bankruptcies, number of bankruptcies in adjacent counties; (ii) Fixed Effects: } \\
\text { county and district-year, where district is one of } 90 \text { judicial districts; (iii) Controls: log of county-year pop- } \\
\text { ulation, log of county-year employment in all non-legal sectors. Sample: All U.S. counties with non-zero } \\
\text { legal employment, omitting Delaware and New York. Period: 1991-1996. Sources: Lopucki BRD, Compu- } \\
\text { stat, CBP, U.S. Census Bureau, BEA, SEC EDGAR. }\end{array}$} \\
\hline
\end{tabular}

\section{G GMM Estimation}

This section describes our GMM estimation from Section 6 in greater detail. We first describe the technical details of the estimation. Then we present some additional GMM robustness results to support our main findings in Table 7.

\section{G.1 GMM Procedure}

We implement this procedure using the Stata GMM package for more information please refer to the documentation for that package.For ease of notation let $i=1, \ldots, N$ index each observation where $N$ is the total number of county-year observations. Let $\mathbf{z}_{i}^{w}$ and $\mathbf{z}_{i}^{n}$ denote the vectors of instruments used for estimation. The $1 \times q_{w}$ vector $\mathbf{z}_{i}^{w}$ is used for $\Delta \epsilon_{i}^{w S}$ and $\Delta \epsilon_{i}^{w U}$; the $1 \times q_{n}$ vector $\mathbf{z}_{i}^{n}$ is used for $\Delta \epsilon_{i}^{n S}$ and $\Delta \epsilon_{i}^{n U}$. Let $q=2 q_{w}+2 q_{n}$. Then, for each observation, there 
are $q$ population moment conditions given by

$$
\mathbb{E}\left[\begin{array}{c}
\left(\mathbf{z}_{i}^{w}\right)^{\prime} \cdot \Delta \epsilon_{i}^{w S} \\
\left(\mathbf{z}_{i}^{w}\right)^{\prime} \cdot \Delta \epsilon_{i}^{w U} \\
\left(\mathbf{z}_{i}^{n}\right)^{\prime} \cdot \Delta \epsilon_{i}^{n S} \\
\left(\mathbf{z}_{i}^{n}\right)^{\prime} \cdot \Delta \epsilon_{i}^{n U}
\end{array}\right]=\mathbf{0} \quad \forall i=1, \ldots, N
$$

For our preferred specification this corresponds to 14 moment conditions where

$$
\begin{aligned}
& \mathbf{z}_{i}^{w}=\left[\begin{array}{llll}
\left(B R_{c, t-1}\right) & \left(B R_{c, t-1}\right)^{2} & \left(B R_{c, t-1}\right)^{3} & \left(B R_{c, t-1}\right)^{4}
\end{array}\right], \\
& \mathbf{z}_{i}^{n}=\left[\begin{array}{lll}
B R_{c, t} & \left(B R_{c, t-1}\right) & 1
\end{array}\right] .
\end{aligned}
$$

We denote the vector of parameters to be estimated as $\boldsymbol{\beta}=\left[\begin{array}{lll}1 / \rho_{s} & 1 / \rho_{u} & \alpha\end{array}\right]^{\prime}$. By stacking the moment equations we can write them more compactly as $\mathbf{Z}_{i}^{\prime} \mathbf{u}_{i}(\boldsymbol{\beta})$ with the $4 \times q$ instrument matrix $\mathbf{Z}_{i}$ and the $4 \times 1$ vector of residuals $\mathbf{u}_{i}(\boldsymbol{\beta})$ defined as

$$
\mathbf{Z}_{i} \equiv\left[\begin{array}{cccc}
\mathbf{z}_{i}^{w} & 0 & 0 & 0 \\
0 & \mathbf{z}_{i}^{w} & 0 & 0 \\
0 & 0 & \mathbf{z}_{i}^{n} & 0 \\
0 & 0 & 0 & \mathbf{z}_{i}^{n}
\end{array}\right] \quad \text { and } \quad \mathbf{u}_{i}(\boldsymbol{\beta}) \equiv\left[\begin{array}{c}
\Delta \epsilon_{i}^{w S} \\
\Delta \epsilon_{i}^{w U} \\
\Delta \epsilon_{i}^{n S} \\
\Delta \epsilon_{i}^{n U}
\end{array}\right]
$$

Then the usual GMM criterion function can be written as

$$
Q(\boldsymbol{\beta}, \mathbf{W})=\left\{\frac{1}{N} \sum_{i=1}^{N} \mathbf{Z}_{i}^{\prime} \mathbf{u}_{i}(\boldsymbol{\beta})\right\}^{\prime} \mathbf{W}\left\{\frac{1}{N} \sum_{i=1}^{N} \mathbf{Z}_{i}^{\prime} \mathbf{u}_{i}(\boldsymbol{\beta})\right\}
$$

for some positive semi definite $4 \times 4$ weight matrix $\mathbf{W}$.

The two-step GMM procedure first obtains a preliminary estimate of

$$
\hat{\boldsymbol{\beta}}_{1}=\underset{\boldsymbol{\beta}}{\operatorname{argmin}} Q\left(\boldsymbol{\beta}, \hat{\mathbf{W}}_{1}\right)
$$

using the identity matrix as the first stage weight matrix $\hat{\mathbf{W}}_{1}$. We then update $\hat{\mathbf{W}}_{2}$ to be the estimate of the inverse variance-covariance matrix for $\mathbf{Z}_{i}^{\prime} \mathbf{u}_{i}(\boldsymbol{\beta})$ 
clustered at the county level. To do this first we calculate

$$
\boldsymbol{\lambda}_{c}=\frac{1}{N} \sum_{i \in c} \mathbf{Z}_{i}^{\prime} \mathbf{u}_{i}\left(\hat{\boldsymbol{\beta}}_{1}\right)
$$

for each county $c$. Then $\operatorname{cov}\left(\mathbf{Z}_{i}^{\prime} \mathbf{u}_{i}(\boldsymbol{\beta})\right)$ is estimated as

$$
\boldsymbol{\Lambda}=\frac{1}{N} \sum_{c=1}^{N_{c}} \boldsymbol{\lambda}_{c} \boldsymbol{\lambda}_{c}^{\prime}
$$

where $N_{c}$ is the number of counties. Finally setting $\hat{\mathbf{W}}_{2}=\boldsymbol{\Lambda}^{-1}$ for the second stage gives our GMM parameter estimates

$$
\hat{\boldsymbol{\beta}}_{\mathrm{GMM}}=\underset{\boldsymbol{\beta}}{\operatorname{argmin}} Q\left(\boldsymbol{\beta}, \hat{\mathbf{W}}_{2}\right)
$$

Inference is done by calculating the usual variance covariance matrix

$$
\operatorname{Var}\left(\hat{\boldsymbol{\beta}}_{\mathrm{GMM}}\right)=\frac{1}{N}\left(\overline{\mathbf{G}}\left(\hat{\boldsymbol{\beta}}_{\mathrm{GMM}}\right)^{\prime} \hat{\mathbf{W}}_{2} \overline{\mathbf{G}}\left(\hat{\boldsymbol{\beta}}_{\mathrm{GMM}}\right)\right)^{-1}
$$

where

$$
\overline{\mathbf{G}}\left(\hat{\boldsymbol{\beta}}_{\mathrm{GMM}}\right)=\left.\frac{1}{N} \sum_{i=1}^{N} \mathbf{Z}_{i}^{\prime} \frac{\partial \mathbf{u}_{i}(\boldsymbol{\beta})}{\boldsymbol{\beta}^{\prime}}\right|_{\boldsymbol{\beta}=\hat{\boldsymbol{\beta}}_{\mathrm{GMM}}} .
$$

\section{G.2 GMM Alternative Specifications}

In order to address concerns regarding our GMM specification we present results for alternative specifications. Table 19 details the instruments used for each equation in the alternative specifications, and Table 20 presents the results. Though many of the results are not as strong as our baseline specification, they all support our main findings presented in Section 6.1.

The first concern we will address regards our choice of sample. We calibrate our preferred specification (Baseline) using 1991-2001 in order to get a larger sample size. The BLS data we use for skilled and unskilled has only 1208 observations when only the Court Competition Era is considered. However when we limit the sample to only the Court Competition Era we find results 
that are very similar to our baseline specification albeit with lower significance due to the smaller sample size.

Next we address the choice of instruments in several ways. All specifications make use of the sources of exogenous variation in $\theta_{c, t}$ which are $B R_{c, t}$ and $B R_{c, t-1}$. The first additional specification we check is the baseline specification without a constant term as an instrument for $\Delta \epsilon_{c, t}^{n S}$ and $\Delta \epsilon_{c, t}^{n U}$ to address concerns that $\mathbb{E}\left[\Delta \epsilon_{i}^{n S}\right]=0$ and $\mathbb{E}\left[\Delta \epsilon_{i}^{n U}\right]=0$ may not be valid moment conditions. These results however support our main findings albeit with lower significance because when all instruments are constructed from $B R_{c, t}$ and $B R_{c, t-1}$ the model becomes harder to identify due to the fact that $B R_{c, t}$ and $B R_{c, t-1}$ equal zero for the majority of observations. This brings us to the next additional specification where we include a constant term as an instrument for all of the moment conditions. Including this specification gives the model considerably more variation to use for identification because the instruments $B R_{c, t}$ and $B R_{c, t-1}$ equal zero for the majority of observations. With this additional variation we once again find results that support our baseline specification, and as expected has a $\mathrm{J}$ statistic that has a somewhat smaller $p$ value. Finally to address concerns with including a variety of non-linear transformations of $B R_{c, t}$ and $B R_{c, t-1}$ as instruments we present a simplified instrument specification without these additional terms. By not including these terms this greatly reduces the number of moment conditions and subsequently the amount of variation to be used for identification. As a result there is not enough variation in the model to properly identify the $\alpha$ returns to scale parameter, which gives an extremely large standard error for the estimate. However, even with larger standard errors, we find evidence to support our baseline models estimate of the elasticity of labor supply $1 / \rho_{s}$ and $1 / \rho_{u}$.

Table 19: Alternative GMM Instrument Specifications

\begin{tabular}{lcc}
\hline & Instruments for $\Delta \epsilon_{c, t}^{w S}$ and $\Delta \epsilon_{c, t}^{w U}$ & Instruments for $\Delta \epsilon_{c, t}^{n S}$ and $\Delta \epsilon_{c, t}^{n U}$ \\
\hline Baseline & $\left\{\left(B R_{c, t-1}\right),\left(B R_{c, t-1}\right)^{2},\left(B R_{c, t-1}\right)^{3},\left(B R_{c, t-1}\right)^{4}\right\}$ & $\left\{B R_{c, t},\left(B R_{c, t-1}\right)\right.$, constant $\}$ \\
Court Competition Era & $\left\{\left(B R_{c, t-1}\right),\left(B R_{c, t-1}\right)^{2},\left(B R_{c, t-1}\right)^{3},\left(B R_{c, t-1}\right)^{4}\right\}$ & $\left\{B R_{c, t},\left(B R_{c, t-1}\right)\right.$, constant $\}$ \\
No Constant & $\left\{\left(B R_{c, t-1}\right),\left(B R_{c, t-1}\right)^{2},\left(B R_{c, t-1}\right)^{3},\left(B R_{c, t-1}\right)^{4}\right\}$ & $\left\{B R_{c, t},\left(B R_{c, t-1}\right)\right\}$ \\
With Constant & $\left\{\left(B R_{c, t-1}\right),\left(B R_{c, t-1}\right)^{2},\left(B R_{c, t-1}\right)^{3},\left(B R_{c, t-1}\right)^{4}\right.$, constant $\}$ & $\left\{B R_{c, t},\left(B R_{c, t-1}\right)\right.$, constant $\}$ \\
Simplified Instruments & $\left\{\left(B R_{c, t-1}\right)\right\}$ & $\left\{B R_{c, t}\right.$, constant $\}$ \\
\hline
\end{tabular}


Table 20: Alternative GMM Instrument Specifications

\begin{tabular}{lccccccc}
\hline & $1 / \rho_{s}$ & $1 / \rho_{u}$ & $\alpha$ & J-stat & $E V_{s}$ & $E V_{u}$ & Obs. \\
\hline Baseline & $0.0853^{* * *}$ & $0.264^{* *}$ & $1.292^{* * *}$ & 12.592 & $0.74 \%$ & $0.77 \%$ & 2370 \\
& $(0.0307)$ & $(0.120)$ & $(0.150)$ & $(p=0.32)$ & & & \\
Court Competition Era & $0.0792^{*}$ & 0.195 & $1.397^{* * *}$ & 16.921 & $0.20 \%$ & $0.21 \%$ & 1208 \\
& $(0.0423)$ & $(0.164)$ & $(0.101)$ & $(p=0.11)$ & & & \\
No Constant & 0.0223 & 0.00933 & $1.268^{* * *}$ & 10.2235 & $0.65 \%$ & $0.64 \%$ & 2370 \\
\multirow{5}{*}{ With Constant } & $(0.0519)$ & $(0.118)$ & $(0.133)$ & $(p=0.33)$ & & & \\
\multirow{3}{*}{ Simplified Instruments } & $0.113^{* * *}$ & $0.280^{* *}$ & $1.294^{* * *}$ & 17.8513 & $0.76 \%$ & $0.79 \%$ & 2370 \\
& $(0.0289)$ & $(0.108)$ & $(0.149)$ & $(p=0.16)$ & & & \\
& $0.0750^{* *}$ & $0.238^{*}$ & -7.942 & 5.024 & $0.33 \%$ & $0.34 \%$ & 2370 \\
\hline
\end{tabular}

Standard errors clustered at county level in parentheses

${ }^{*} p<0.1,{ }^{* *} p<0.05,{ }^{* * *} p<0.01$

Note: GMM regression estimates. Wages and unemployment are detrended prior to estimation using countyyear population, log of county-year employment in all non-legal sectors with fixed effects for county and district-year, where district is one of 90 judicial districts. Sample: all U.S. counties with non-zero legal employment. Sources: Lopucki BRD, Compustat, CBP, U.S. Census Bureau, BEA, SEC EDGAR, BLS. EV $E V_{u}$ reported using $E I S=0.5(\sigma=2)$.

\section{H Database Creation}

1. Clean Standard and Poor's Compustat Database Database. ${ }^{32}$ We do this in a similar manner to Corbae and D'Erasmo (2021), for a more detailed description see Appendix A-1 in Corbae and D'Erasmo (2021).

- Remove duplicate entries, remove non USA firms, remove firms in legal sector $(\mathrm{SIC}=8111)$, and remove years outside of LP range (1980-2014).

- Create bankruptcy indicators in a similar manner to Corbae and D'Erasmo (2021). Ch11 if "fresh start accounting" and no deletion, Ch11 if "bankruptcy" and no deletion, Ch11 if "bankruptcy" and deletion with merger delete reason in CS.

2. Collect data for Compustat bankruptcies using court records.

\footnotetext{
${ }^{32}$ Information on the S\&P Compustat data can be found in the Compustat User Guide.
} 
- Use bankruptcy indicators from Compustat to create list of companies that appear to have undergone Chapter 11 bankruptcy.

- Use SEC EDGAR to find each companies EIN code.

- Search PACER Case Locator using companies EIN codes to find court records for bankruptcies. (Includes filing location)

- Supplement missing cases with SEC filings found using Bloomberg Lawwebsite when necessary.

3. Create firm-level database.

- Merge Lopucki BRD, Compustat, and data scraped from PACER, to create complete panel data of publicly traded companies with information Chapter 11 bankruptcies.

- Drop bankruptcy observations for legal industry from database. (SIC $=8111)$

- Determine bankruptcy occurred when indicated by either Lopucki BRD or one of the bankruptcy indicators from Compustat.

- Determine if forum shopping occurred if either indicated by Lopucki BRD or if the PACER filing location does not match the district where the firm was headquartered (Note this does NOT capture within district forum shopping!). If filing location data missing, assume firm did not forum shop.

4. Create County-Year panel data used for regressions.

- Aggregate firm-level database to county-year level and merge with CBP employment data.

- Include U.S. Census Bureau, BLS, and BEA data for controls and additional exercises. 